\title{
Vliv atraktivity kontextu matematické slovní úlohy na řešitelský proces
}

\section{The Influence of the Attractiveness of Context of a Mathematical Word Problem on Solving Processes}

\author{
Radka Havlíčková ${ }^{1}$ \\ ${ }^{1}$ Pedagogická fakulta, Univerzita Karlova, M. Rettigové 4, 11639 Praha 1, Česká republika; radka.havlickova@pedf.cuni.cz
}

Výzkumy zabývající se řešením matematických slovních úloh poukazují na to, že rozdíly v úspěšnosti nejsou dány pouze rozdílnou úrovní kognitivních schopností žáků, ale že svou roli sehrává také motivace. V této studii jsme se proto zaměřili na kontext, jakožto nematematickou složku slovní úlohy, a zjištovali jeho vliv na úspěšnost žáků při jejím řešení. Sledovaným aspektem kontextu byla jeho potenciální atraktivita zjištovali jsme, zda žáci budou úspěšnější v řešení slovních úloh s prvky pohádky, science fiction a humoru než v úlohách se stejnou strukturou, ale s neutrálním kontextem. Žáky 5. a 6. ročníku základní školy $\left(n_{5}=623, n_{6}=291\right)$ jsme rozdělili do dvou výkonově srovnatelných skupin a každé z nich předložili jednu z variant - atraktivní nebo neutrální. Pro vyhodnocení výsledků kvantitativního šetření jsme použili Item Response Theory, která nám umožnila sledovat obtížnost úlohy v závislosti na latentní schopnosti jednotlivých žáků a poskytla informaci o diskriminačních vlastnostech úloh. Kromě úspěšnosti jsme v rámci kvalitativního šetření zjištovali také rozdíly v oblasti řešitelských strategií a chyb. Ukázalo se, že atraktivní kontexty mohou za určitých podmínek vést ke zvýšení snahy žáků o jejich vyřešení a v některých př́ípadech i k mírnému zvýšení úspěšnosti řešení. Studie také ukázala, že při variování kontextů úloh je obtížné zachovat ostatní parametry úlohy beze změn, které by se odrážely v náročnosti situačního modelu úlohy, a upozornila na určitou nekonzistenci výsledků některých výzkumů.

Research on mathematical word problems suggests that differences in success are not only due to different levels of pupils' cognitive abilities but that their motivation plays a role, too. Therefore, in this study, we focused on the context as a non-mathematical parameter of word problems and investigated its influence on pupils' success in solving the problems. We focused on the potential attractiveness of the context and investigated whether pupils would be more successful in solving word problems with elements of fairy tale, science fiction or humour than in the case of similar problems with the same structure but with a neutral context. Pupils of the 5th and 6th grades of primary school $\left(n_{5}=623, n_{6}=291\right)$ were divided into two groups of a comparable ability and each was presented with one of the variants - either attractive or neutral. To evaluate the results quantitatively, we used the Item Response Theory which allowed us to determine the difficulty of the task depending on the latent abilities of pupils and enabled us to assess the discriminating properties of the problems. In the qualitative part of the study, we investigated the differences between pupils in terms of their solving strategies and errors. It was established that the attractive context could, under certain conditions, stimulate the pupils' efforts towards solving the problems and, in some cases, can slightly improve the success rate. The study also showed that when varying the context, it is difficult to keep the other parameters of the problem without changes, possibly influencing the complexity of the situational model, and pointed out inconsistencies in some research results.

\section{Klíčová slova:} slovní úloha, atraktivita kontextu, motivace, úspěšnost, povrchová řešitelská stategie.

Zasláno 2/2020

Revidováno 6/2020

Prijato 6/2020

\section{1 Úvod}

Přes velkou pozornost, která je slovním úlohám věnována ve výuce matematiky, jsou tyto úlohy považovány žáky i učiteli za náročné a neoblíbené učivo (Nesher \& Teubal, 1975; Verschaffel et al., 1992; Rendl et al., 2013). Z našeho předchozího výzkumu¹ (Vondrová et al., 2019) vyplynulo, že častou příčinou nezdaru při řešení slovní úlohy je používání povrchových řešitelských strategií. Žáci si při řešení úlohy nevytvářejí představu o situaci a rovnou přistupují k tvorbě matematického modelu, který pak často neodpovídá popisované situaci. Jednou z příčin takového př́istupu může být také nízká motivace žáků úlohu řešit.

\footnotetext{
${ }^{1}$ Výzkum byl realizován v rámci projektu GA ČR 16-06134S Slovni úlohy jako klič k aplikaci a porozumění matematickým pojmům v letech 2016-2018.
} 
Výzkumy zabývající se obtížemi žáků se slovními úlohami hledají jejich původ mj. v různých překážkách, které staví do cesty $\mathrm{k}$ úspěšnému řešení samy úlohy. Velká pozornost je věnována např́íklad jazykové formulaci, pořadí zadaných informací, matematickým parametrům úlohy aj. (Hembree, 1992; Verschaffel \& De Corte, 1993; Nesher et al., 2003; Palm, 2008; Daroczy et al., 2015). Kontext slovních úloh, ke kterému nyní obracíme pozornost, je jedním z méně zkoumaných parametrů (OECD, 2010; Beswick, 2011). Studie, jejíž dílčí výsledky předkládáme, vychází z předpokladu, že zvýšení zájmu žáků o slovní úlohu může zvýšit jejich úspěšnost při jejím řešení. Cílem studie je zjistit, jaký vliv má atraktivita kontextu slovní úlohy na úspěšnost a řešitelské chování žáků v úloze. Využijeme přitom data, která jsme získali v rámci již zmíněného projektu GA ČR, i jeho metodologii (Vondrová et al., 2019).

\section{Teoretická východiska}

Nejdříve vymezíme klíčové pojmy, představíme fáze řešitelského procesu slovních úloh a závěry vybraných výzkumů sledujících vliv různých charakteristik kontextu na úspěšnost žáka.

\subsection{Slovní úloha a její kontext}

V literatuře se setkáme s různými vymezeními pojmu slovní úloha. $V$ následujícím výběru se zaměříme zejména na tu jejich rovinu, která se dotýká kontextu. Verschaffel et al. (2000, s. ix) vymezují slovní úlohu jako:

Slovní popis problémových situací obsahující jednu nebo více otázek, na které lze odpovědět pomocí aplikace matematických operací na číselné údaje, které jsou uvedeny v zadání.

Autoři dodávají, že typickou formou slovní úlohy je stručný, zhuštěný, text popisující esenciální prvky určité situace, $v$ níž jsou některé číselné informace explicitně dány a jiné ne a s níž je řešitel konfrontován v hodině matematiky. Jeho úkolem je získat číselnou odpověd’ na položenou otázku, a to explicitně a za výhradního použití číselných údajů uvedených v textu nebo jejich vzájemných vztahů, které lze z textu úlohy vyvodit. $\mathrm{V}$ tomto vymezení najdeme kromě poznámky o vazbě na skutečnou nebo představitelnou situaci také zmínku o vztazích mezi údaji, které nejsou explicitně vyjádřeny, čímž se do hry dostává kontext.

Vondrová et al. (2019) ve svém pojetí slovní úlohy od kontextu vycházejí. Slovní úlohu vymezují jako problém, který zahrnuje určitý kontext (nematematický, reálný, pseudo-reálný nebo fiktivní), uvnitř něhož jsou dány určité číselné informace a v rámci kterého je položena otázka (otázky), kterou/é mají žáci zodpovědět za použití svých matematických znalostí a „mimoškolních“ zkušeností. Toto vymezení bere v úvahu navíc i žákovu zkušenost mimo školu, tedy zkušenost z reálného života, na kterou může slovní úloha navázat. Autoři dále rozlišují kontext úlohy z hlediska lingvistiky do tří vrstev - slovní, situační a zkušenostni (s. 17). Všechny tři vrstvy mohou potenciálně ovlivňovat subjektivní obtížnost úlohy.

Také v pojetí Hejného (2003) je jedním ze dvou požadavků na slovní úlohu vazba na životní zkušenost. Termínem slovní úloha rozumí: „matematickou úlohu, která vyžaduje jazykové porozumění a přesah do životní zkušenosti“ (s. 3). Např́íklad úloha: „Součet dvou čísel je 19 a jejich rozdíl 3. Jaká to jsou čísla?“ vyžaduje porozumění slovům (na rozdíl od úlohy $5 x+4=19$ ), splňuje tedy první podmínku, ale nelze ji pokládat za slovní úlohu, protože $\mathrm{k}$ jejímu vyřešení nejsou třeba životní zkušenosti, je vázána čistě na svět matematiky. V dalších úvahách Hejného nacházíme inspiraci v anatomickém způsobu nahlížení na slovní úlohu (s. 3-5). Podle něj je slovní úloha tvořena čtyřmi různými vzájemně se prostupujícími vrstvami. Vrstvou objektů (osoby, předměty, události, ...), o kterých úloha hovoří, at již přímo nebo nepř́mo, dále vrstvou vztahů mezi těmito objekty, z nichž nejvýznamnější jsou ty, které spojují objekty poukazující na číslo. Další vrstvou je vrstva příběhu či situace, která vytváří v mysli člověka základní představu o úloze a přináší výzvu, která navodí a orientuje řešitelský proces (sem bychom zařadili kontext). Poslední vrstvou je vrstva matematického modelu.

$\mathrm{S}$ přesným vymezením pojmu kontext slovní úlohy se v odborné literatuře nesetkáme. Bývá chápán intuitivně nebo je popisován skrze svou funkci ve slovní úloze (viz ukázky výše) nebo jako součást širšího pojmu, tzv. učení se v kontextu (Meyer et al., 2001; Boaler, 1993). Borasi(ová) (1986) stručně vymezuje kontext jako situaci, $\mathrm{v}$ níž je zasazen určitý problém a která řešiteli poskytuje informace, které mu jej umožňují vyřešit. V návaznosti na výše zmíněná vymezení pojmu slovní úloha budeme kontext chápat jako situaci, do které je zasazen určitý matematický problém; jako nematematickou složku slovní úlohy, která poskytuje informace o objektech úlohy a vztazích mezi nimi a navazuje na skutečnosti, které nejsou explicitně vyjádřeny, ale jsou dostupné ve zkušenostech řešitele. Kontext slovní úlohy může tvořit i stručnou dějovou linku nebo nabývat podoby krátkého př́iběhu. 


\subsection{Proces řešení slovních úloh a povrchové strategie}

Proces řešení slovní úlohy rozdělují různí autoři do různých fází (např. Reusser, 1990; Novotná, 2000; Hejný, 2003). První fáze obvykle spočívá ve zpracování, interpretaci textu, porozumění v jazykové rovině (vytvoření sémantického modelu úlohy). Ve druhé fázi dochází k porozumění popisované situaci, a to skrze uvědomění si jejích objektů a jejich vzájemných vztahů. V této fázi se rozbíhá řešitelský proces, vytvář́ se situační model úlohy. Třetí fází je tzv. matematizace, vytváření matematického modelu úlohy, neboli převedení situace do jazyka matematiky (rovnice, schématu, výpočtu, obrázku aj.). Následuje fáze výpočtu, tedy aplikace matematických pravidel a postupů. Proces uzavírá interpretace nalezeného číselného výsledku ve vztahu $\mathrm{k}$ položené otázce či situaci a tvorba slovní odpovědi, která dává tomuto výsledku význam.

Schopnost řešit matematickou slovní úlohu může být u žáků oslabena v kterékoliv jmenované fázi. Protože se v této studii zabýváme kontextem slovní úlohy čili vrstvou situace, podstatná je pro nás druhá fáze řešitelského procesu - tvorba situačního modelu. Z našeho výzkumu (Vondrová et al., 2019) vyplynulo, že častou př́ičinou nezdaru je, že žáci si z nějakého důvodu nevytvoří situační model úlohy, ale přikročí rovnou $\mathrm{k}$ modelu matematickému. Ten vychází pouze z izolovaných částí textu (např. čísel a k nim přidružených slov), nezrcadlí vztahy mezi objekty apod. Takové řešitelské chování označujeme jako používání povrchové strategie. Důvodem pro nevytvoření situačního modelu může být kromě náročnosti slovní úlohy pro daného žáka a s ní spojeného kognitivního přetížení a zahlcení jeho pracovní paměti (např. Sweller, 2010) také zautomatizovaný přístup k řešení slovních úloh stejného typu nebo žákův nezájem o tuto činnost. Další možné přičiny povrchových strategií popisuje Vondrová (2020), mj. např́klad didaktické přičiny (učení se strategii signálních slov, stereotypnost úloh nabízených učebnicemi) a psychologické př́činy (naučená bezmocnost, nízká sebedůvěra žáka ve vlastní schopnost řešit slovní úlohy).

Vhodný kontext slovní úlohy by mohl posloužit jako prostředek $\mathrm{k}$ překlenutí nezájmu žáků o text úlohy, podpořit jejich snahu vytvořit si situační model, a snížit tak tendenci používat povrchové strategie. O motivačním efektu kontextu lze přitom uvažovat až v př́padě, že je splněna podmínka smysluplnosti a přiměřenosti úlohy pro jednotlivce - bude-li úkol pro žáka př́liš snadný, nebo naopak obtížný, motivace bude nízká bez ohledu na kontext (Man \& Mareš, 2005).

\subsection{Vliv vybraných charakteristik kontextu na výkon žáků}

Kontexty úlohy můžeme různým způsobem třídit. Např. v testování PISA jsou rozlišeny čtyři okruhy kontextů: personální (každodenní aktivity, osobní zkušenosti), vzdělávací a profesní (spíše situace uměle vytvořené s konkrétním výukovým záměrem), veřejný (každodenní interakce s okolním prostředím) a vědecký (čistě matematické problémy nebo problémy z vědeckého světa) (OECD, 2010). V literatuře se objevují tzv. kontexty z reálného světa, fantazijní nebo pseudo-reálné kontexty, kontexty dívči či chlapecké, familiární (žákům důvěrně známé) či neznámé (zejména vědecké), personalizované (v nichž figurují jména nebo osobnosti samotných řešitelů), kontexty týkající se různých témat - sportu, zvírat, módy apod.

\subsubsection{Realita vs. fikce}

Velká pozornost je ve výzkumu věnována slovním úlohám s kontextem z reálného života, které podle některých autorů mohou vést $\mathrm{k}$ lepším žákovským výsledkům $\mathrm{v}$ důsledku snazší představitelnosti řešeného problému i větší motivace (Verschaffel et al., 2000; Palm, 2008). Výsledky však nejsou jednoznačné. Např. metaanalýza studií (Gersten et al., 2008) potvrdila, že při výuce založené na reálných kontextech se sice výkony žáků zlepšují, ale jen u úloh podobného typu. I některé další výzkumy potvrzují pozitivní efekt (Bottge, 1999; Cooper \& Harries, 2002). Jiné naopak ukazují, že žáci mají problém přenést svoje znalosti z reálného světa do řešení slovní úlohy. Studie (De Bock et al., 2003) ukázala, že úlohy s autentickým kontextem mohou mít na žákovskou úspěšnost dokonce negativní vliv.

Wiest(ová) (1998) porovnávala úlohy z reálného světa dětí, reálného světa dospělých a úlohy s fantazijními kontexty. Kromě vlivu kontextu na úspěšnost žáků 4. a 6. ročníků $(n=273)$, kde se velké rozdíly neukázaly, zjištovala také jejich preference. Ukázalo se, že nejméně preferována (statisticky významně), byla mezi žáky úloha ze světa dospělých. Preference ostatních typů byly zhruba vyrovnané, lehce ve prospěch fantasy kontextů. Zajímavé byly komentáře žáků, kteří popisovali vliv kontextu úlohy na jejich zaujetí a zpưsob řešení. Zmiňovali např́iklad, že některé úlohy řešili s větším úsilím, protože byly zajímavé nebo humorné, že se snažili více, když se jim úloha líbila nebo naopak jim to „špatně myslelo“, když se jim úloha nelíbila. 


\subsubsection{Familiární vs. nefamiliární kontext}

Rozsáhlá metaanalýza studií (Hembree, 1992) zabývajících se mj. familiárností kontextů (kontextů známých, blízkých, zohledňujících realitu žitou dětmi) ukázala, že familiární kontexty vedly ve čtyřech studiích (5. a 6. ročníky +12 . ročníky, $n=1608) \mathrm{k}$ výrazně většímu počtu úspěšných řešení než kontexty, které byly žákům neznámé. Vliv kontextů fantazijních (imaginative) vs. obvyklých (ordinary) (11 výzkumů, 5.-9. ročníky, $n=4308$ ) se ovšem neprokázal.

Familiárností kontextu se v našem prostředí zabývaly také Vondrová a Novotná (2017). Srovnávaly úspěšnost žáků 6. ročníků $(n=353)$ v závislosti na miře známosti kontextu a uspořádání informací v zadání úlohy. Familiární kontext se týkal skládání puzzle, kde lze předpokládat, že s ním má většina žáků osobní zkušenost. Nefamiliární kontext byl z prostředí chemické laboratoře a výroby léčiva. Zatímco pořadí informací v textu mělo statisticky významný vliv na úspěšnost žáků, výsledky pro kontext nebyly jednoznačné - v jedné dvojici úloh byly úlohy o skládání puzzle výrazněji úspěšnější (94 \% vs. 83 \%), u druhé dvojice nebyl prakticky žádný rozdíl.

\subsubsection{Kontext dívčí vs. chlapecký}

Zohar(ová) a Gershikov(ová) (2008) zjištovaly, zda kontexty matematických problémů ovlivňují stejně děvčata i chlapce, a to ve třech různých věkových skupinách (1., 2.-4., 5.-6. ročníky) $(n=523)$. Žáci řešili tři typy úloh: se stereotypně chlapeckým, stereotypně dívčím a genderově neutrálním kontextem. Ukázalo se, že dívky byly ovlivněny kontexty výrazně více než chlapci, kteří např́ič všemi věkovými kategoriemi podávali vyrovnaný výkon ve všech kontextech. V neutrálním kontextu dosahovala obě pohlaví srovnatelných výsledků ve všech věkových skupinách, dívky byly lehce úspěšnějšś. V chlapeckých kontextech byly výrazně lepší chlapci ve všech sledovaných věkových kategoriích a rozdíl se s rostoucím věkem snižoval. $\mathrm{V}$ dívčích kontextech záleželo na věku. Zatímco $\mathrm{v} 1$. ročnících byly dívky trochu úspěšnější než chlapci, $\mathrm{v}$ druhé věkové kategorii se tento rozdíl zmenšil a v 5.-6. ročnících došlo $\mathrm{k}$ obrácení poměru, tedy chlapci byli v dívčích kontextech významně úspěšnější než děvčata. Vysvětlení autorky hledají v kombinaci afektivních a kognitivních faktorů. Dívky v př́slušném věku mají o dívčí kontexty zvýšený zájem, a věnují tak velkou pozornost detailům na úkor hlubších komponent úlohy, což může mít za následek snížení kognitivní výkonnosti.

K jiným závěrům dospěli Murphy(ová) a Ross (1990), kteří zjistili, že žáci 8. ročníku $(n=252)$ a zejména chlapci výrazně preferují kontexty, ve kterých vystupuje „v hlavní roli“ postava se shodným pohlavím, a že dívky jsou v řešení „chlapeckých“ úloh úspěšnější než chlapci v řešení „dívčích úloh“. Významné rozdíly založené na socioekonomickém zázemí žáků zjištěny nebyly. Na děti z venkova však měl kontext větší vliv. Když dostaly úlohu s preferovanou postavou, dosahovaly lepších výsledků než žáci z př́městské školy u úloh s preferovaným kontextem.

\subsubsection{Personalizovaný vs. nepersonalizovaný kontext}

Další studie se zaměřují na působení tzv. personalizace kontextu slovní úlohy. Jeho podstatou je přiblížení se konkrétnímu žákovi-řešiteli nebo skupině žákủ, například prostř̌ednictvím pojmenování postavy vystupující v úloze po žákovi-řešiteli či použitím objektů, situací, které jsou pro konkrétního žáka aktuální. López(ová) a Sullivan (1992) ve své studii vymezili tři stupně kontextů z hlediska personalizace: individualizované, skupinově individualizované (zohledňující zájmy, charakteristiky určité skupiny) a neindividualizované (non-personalized). Zaměřili se na žáky 7. ročníků $(n=123)$ a podle jejich životopisných údajů sestavili několik jednokrokových a dvoukrokových úloh. Analýza ukázala výrazný pozitivní vliv personalizovaných (individualizovaných i skupinových) úloh na míru zaujetí úlohou a významně větší úspěšnost při řešení dvoukrokových úloh. U jednokrokových úloh nebyl vliv tak významný. Skupinově individualizované kontexty přitom neměly takovou sílu jako kontexty směrované na konkrétního řešitele. Naproti tomu zmiňovaná metaanalýza (Hembree, 1992) tento efekt nepotvrzuje. Šest výzkumů zaměřných na personální a impersonální kontexty u žáků 4. a 6 . ročníků $(n=579)$ neukazuje žádné statisticky významné rozdíly.

\subsection{Atraktivní kontext}

Některé výše uvedené aspekty kontextu (personalizace, realita, gender) a další můžeme nahližet též z perspektivy atraktivity.

Jako úlohy s atraktivním kontextem budeme označovat takové, které mají ambice žáka zaujmout. Mohou být založené na známém příběhu či pohádce nebo vytvářet př́běh nový. Vystupující objekty či postavy mohou být smyšlené, nereálné, stejně jako v pohádkách. Zviřratům mohou být připisovány lidské vlastnosti, lidem nadlidské schopnosti. Stejně jako v pohádkách v nich nepředkládáme př́íběh jako 
pravdivý a nepožadujeme po čtenáři, aby věřil v jeho skutečnost. Řešitel úlohy, stejně jako čtenář pohádky, zde přistupuje na jakousi nevyslovenou dohodu a nabízenou fikci přijímá ${ }^{2}$. Kontextově atraktivní úlohy, zkráceně atraktivní, mohou vycházet i z každodenní reality, ovšem s patrnou snahou vzbudit řešitelovu zvědavost, přitáhnout jeho pozornost či vyvolat silnou potřebu úlohu vyřešit. Prostředkem může být např. humor, personalizace, nečekané vyústění popisované situace či aktuálnost nebo naléhavost tématu. Za atraktivní úlohu budeme považovat takovou, která splňuje alespoň jedno z následujících kritérií: námět úlohy je pro žáka aktuální, čerpá svůj námět v pohádce či př́íběhu, vyskytují se v ní nereálné objekty, postavy či situace, rozporuje běžnou lidskou zkušenost (např. porušuje fyzikální zákony), obsahuje vtip, překvapivý moment.

Ulohy kontextově neutrální, zkráceně neutrální, popisují více či méně reálné situace z každodenního života dětí či dospělých. Neoperují s nereálnými objekty, postavami ani situacemi, jsou v souladu s lidskou zkušeností, nerozporují např. fyzikální zákony a nemají zároveň výrazné ambice žáka zaujmout překvapit, potěšit, provokovat, rozesmát nebo se mu jinak přiblížit.

\subsection{Psychologické aspekty}

Studie zabývající se zkoumáním schopností žáků řešit slovní úlohy se častěji zaměřují na oblast kognitivních a metakognitivních dovedností, méně často na motivačně-emoční aspekt (Tzohar-Rozen \& Kramarski, 2014). Odhalování souvislostí mezi kontextem slovní úlohy a emocemi bývá spíše vedlejším produktem takových výzkumů (Beswick, 2011), které mají podobu drobné zmínky či samozřejmého předpokladu bez odkazu na odbornou literaturu. Např. Boaler(ová) (1993) a Murphy(ová) a Ross (1990) zmiňují, že kontext, který vzbudí v řešiteli zájem, jej může motivovat $\mathrm{k}$ vyvinutí většího úsilí při řešení úlohy, nebot jej vybaví větší rezistencí vůči nezdaru. O radosti a jejím pozitivním vlivu na intelektuální práci žáků v obecné rovině se zmiňuje také Hejný (např. 2014, s. 44, 92). Radost považuje za projev vnitřní motivace a za hybnou sílu další práce.

Rheinberg et al. (2001) poukazují na to, že výzkum v době vydání jejich práce ještě neznal, jak přesně motivace funguje, jak ovlivňuje učení či učební výkony, přestože se obecně předpokládá, že vyšší motivace působí na výkon příznivě, a mnohé výzkumy existenci takového vlivu potvrzují. Obecně přijímaná koncepce tzv. motivační psychologie vysvětluje motivaci jako výsledek vzájemného působení dvou faktorů - osobnostního a situačního. V osobnostní rovině jsou to mj. individuální zájmy jakožto oblasti, kterým se jedinec věnuje rád, při kterých se cítí dobře, v situační rovině jsou to kromě obtížnosti úkolu a potenciálního zisku také charakteristiky úlohy, které mohou ovlivňovat míru jedincovy motivace pro daný úkol. Plnění úkolů, u nichž si žák uvědomuje kladné důsledky, ale které se nepotkávají s jeho zájmy, vyžaduje zapojení vůle, prožívá jej jako namáhavé a méně radostné než plnění úkolů, které rezonují s jeho individuálními zájmy (Rheinberg et al., 2001). Kromě individuálních zájmů a potřeb je možné oslovovat univerzální lidské potřeby (zvědavost, autonomie - potřeba samostatného myšlení, potřeba odporovat apod.), jejichž výhodou je, že je lze k motivování využít u většiny jedinců bez hrozby opačného efektu, který je naopak běžný při snaze plošně motivovat skrze zájmy spadající do kategorie individuální; zájmy stejně starých žáků se mohou značně lišit (Krapp, 1998, cit. podle Rheinberg et al., 2001, s. 168).

\subsection{Výzkumná otázka}

Zahraniční výzkumy popsané $\mathrm{v}$ předchozí části ukazují vliv různých aspektů kontextu slovní úlohy na úspěšnost žáků při jejím řešení. V naší studii nabízíme další perspektivu, ze které lze nahližet kontext, a to skrze jeho atraktivitu. Budeme zjištovat, zda se objeví rozdíl v úspěšnosti žáků 5 . a 6 . ročníku při řešení úlohy s neutrálním kontextem a atraktivním kontextem (konkrétně s prvky pohádky, science fiction a humoru). Předpokládáme, že úlohy s atraktivním kontextem budou mít větší procento úspěšných řešitelů než úlohy s neutrálním kontextem, a naopak nižší procento žáků, kteří se o řešení úlohy nepokusí.

\section{Metodologie}

Studie má smíšený charakter. Kvantitativní část vyšetřuje vliv kontextu úlohy na úspěšnost žáků při jejím řešení. Kvalitativní část vycházející z analýzy písemných žákovských řešení z hlediska řešitelských strategií a chyb se snaží objasnit, čím je míra úspěšnosti žáků ovlivněna. Studie je součástí rozsáhlejšího výzkumu testujícího další parametry slovních úloh (Vondrová et al., 2019).

\footnotetext{
${ }^{2}$ Tedy naprŕíklad v úloze „Kouzelný prsten dovede splnit tři přání. Kolik prstenů by potřebovala naše třída, aby se každému z nás splnilo alespoň jedno přání?“ neočekáváme odpověd: „Ani jeden, protože kouzelné prsteny neexistují.", přestože je to v určitém ohledu odpověd’ racionální.
} 


\section{1 Účastníci výzkumu}

Učastníky studie byli žáci 5. a 6. ročníku šesti pražských základních škol. Šlo o spádové školy střední až velké velikosti, bez zaměření, s procentem žáků mluvících cizím jazykem nepřevyšujícím celostátní průměr $2 \%$ a s pestrou skladbou socio-ekonomického zázemí žáků. Testování se účastnili všichni žáci daného ročníku, nebyl dělán žádný výběr ( $n=914 ; 141$ pro Úlohu 1, 629 pro Úlohu 2 a 144 pro Úlohu 3). Žáci byli na základě vstupního testu z českého jazyka a matematiky (a později i na základě výsledků testů předchozích vln testování $)^{3}$ rozděleni do dvou výkonnostně srovnatelných skupin, přičemž bylo zohledněno též kritérium zastoupení žáků s diagnostikovanou SPU a s jiným rodným jazykem.

\subsection{Volba a formulace úloh}

V pilotní studii jsme žákům odpovídajícího věku (4.-6. ročník, $n=19)$ předkládali dvojice úloh (atraktivní a neutrální variantu) a zjištovali jejich preference. Žáci měli např. zvolit úlohu, kterou by v následující chvíli řešili raději nebo vybrat úlohu do plánované učebnice matematiky či pro své kamarády. Následně byli dotazováni na důvod své volby. Poznatky z pilotní studie jsme využili pro úpravu formulace testových úloh a stanovení očekávání (podrobnější výsledky pilotní studie budou uvedeny v disertační práci autorky; Havlíčková, 2020).

Každá ze tř̌́ úloh byla formulována ve dvou různých kontextech, z nichž jeden byl ve výše zmíněném smyslu atraktivní a druhý neutrální. Snahou bylo získat dvě varianty, které se liší pouze kontextem, nikoliv v jiných parametrech, jako je např. matematická struktura úlohy, velikost použitých čísel, pořadí informací, počet a složitost vět a souvětí, typ otázky aj. Úlohy byly zařazeny do testových sešitů společně $\mathrm{s}$ dalšími čtyřmi či pěti úlohami testujícími jiné parametry (pořadí úloh přitom bylo variováno). Každý žák tak obdržel bud’ jednu nebo druhou variantu úlohy. Kromě atraktivní varianty Úlohy 3 se jedná o autorské úlohy.

Text každé úlohy byl diskutován a upravován řešitelským týmem zmíněného projektu GA ČR. Každá z úloh byla také pilotována s 3-7 žáky příslušného věku formou polostrukturovaných rozhovorů.

V první úloze (Lichožrouti) jsme proti sobě postavili neutrální kontext o sušení prádla a kontext čerpající námět z oblíbené ${ }^{4}$ autorské pohádky Lichožrouti (Šrut, 2008). Vyšli jsme z „faktu“, že lichožrouti nemají rádi vodu, a pokusili se při formulaci textu úlohy napodobit styl autora. Jedná se o složenou slovní úlohu, v níž je zapotřebí provést po řadě operaci dělení ( 5 h $30 \min : 2=2$ h 45 min) a operaci odčítání ( $2 \mathrm{~h} 45 \min -20 \min =2 \mathrm{~h} 25 \mathrm{~min}$ ). Prvnímu nebo druhému kroku může ještě předcházet převod čísla zadaného $\mathrm{v}$ hodinách na minuty.

Atraktivní varianta (U1a): Je známo, že lichožrouti nemaji rádi vodu (hrozně dlouho schnou a neradi se ždímají). Proto se ji velkým obloukem vyhýbaji. Takový namočený lichožrout schne bez ždímáni pět a půl hodiny. Když se před sušením vyždímá, uschne za poloviční dobu. A když má to štěstí a najde misto u topení, zkrátí dobu sušení ještě o 20 minut. Za jak dlouho uschne lichožrout, když se před sušením vyždímá a najde místo u topení?

Neutrální varianta (U1n): Je známo, že barevné prádlo na slunci rychleji bledne (barvy ztráceji sytost). Proto se často věši do stínu. Mokré prádlo schne bez ždímáni pět a půl hodiny. Když se před sušením vyždímá, uschne za polovični dobu. A když je pověsíme na sluničko, zkrátí se doba sušení ještě o 20 minut. Za jak dlouho uschne prádlo, když se před sušením vyždímá a pověsí se na sluníčko?

V druhé úloze (Hvězdné impérium) jsme čerpali z žánru science fiction. Atraktivní kontext varianty U2a je inspirován vesmírnou bitvou ${ }^{5}$ (dal by se označit za chlapecký), kontext neutrální varianty U2n čerpá z běžné reality oslavy narozenin (kontext by mohl být bližší děvčatům). Struktura úlohy je aditivní, přičemž její řešení vyžaduje několik na sobě závislých kroků: první $9+4=13$, druhý $9+13=22$, třetí $9+13+22+11=55$. Přestože naší snahou bylo zachovat s výjimkou kontextu další parametry úlohy stejné, k některým změnám jsme se nakonec uchýlili. Rozdíly budeme diskutovat níže.

\footnotetext{
${ }^{3}$ Výzkum měl celkem 4 vlny testování v jedné čtveřici škol a 2 vlny testování ve dvojici jiných škol. Žáci v naší studii byli děleni do výkonnostních skupin na základě vstupních testů (ČJ, M) a dvou testů v př́ípadě Úlohy 2 , na základě vstupních testů (ČJ, M) v případě Úlohy 1 a na základě vstupních testů (ČJ, M) a jednoho testu v př́padě Úlohy 3.

${ }^{4}$ Kniha získala v roce 2009 ocenění Magnesia Litera za nejlepší knihu pro děti a mládež

(https://www.magnesia-litera.cz/kategorie/kniha-pro-deti-a-mladez/). V žebříčku Československé bibliografické databáze je v první čtyřicítce v kategorii Top právě čtené knihy (https://www.cbdb.cz/zebricek-top-prave-ctene-knihy-4-detske). V roce 2016 byla dokonce zfilmována.

${ }^{5}$ Terminologie použitá v textu úlohy je převzata z českého překladu karetní a PC hry Star Realms (autoři hry: Kastle a Dougherty, 2014).
} 
Atraktivní varianta (U2a): Na mateřskou lod’ Hvězdného impéria zaútočila armáda nepřátelských stíhacích faunů. Hvězdné impérium nasadilo do obrany všechny obranné jednotky. Korvety zasáhly celkem 9 faunů, fregatě se podařilo zneškodnit ještě o 4 fauny více. Bitevní křižník zlikvidoval tolik faunů, kolik zneškodnily korvety a fregata dohromady. Mateřská lod’ se útoku ubránila, zbylých 11 stíhacích faunů se stáhlo zpět na svou základnu. Kolik stíhacích faunu bylo v rámci této válečné mise vysláno na likvidaci mateřské lodi Hvězdného impéria?

Neutrální varianta (U2n): Trojčata Nela, Bela a Lea chodila každá do jiné tř́ddy, ale oslavu svých narozenin se rozhodla uspořádat společně. Nela pozvala 9 nejlepšich kamarádek ze své tř́dy. Bela ze své tř́dy pozvala ještě o 4 kamarádky více. Lea pozvala skoro všechny děti ze své tř́dy a ještě holky z gymnastiky, což bylo celkem tolik lidí, kolik pozvala Nela a Bela dohromady. Pozvánku na oslavu dostalo také všech 11 členů jejich rodiny. Kolik lidí celkem bylo na narozeninovou oslavu pozváno?

Třetí úloha (Robin Prchal) je jednoduchá slovní úloha o pohybu. Varianta s atraktivním kontextem U3a byla inspirována humornou slovní úlohou o chlapci Robinovi, který utíká před výpraskem, varianta s neutrálním kontextem U3n byla vytvořena na půdorysu U3a za použití objektů typických pro úlohy o pohybu (cyklista a traktor). Úlohu lze na úrovni 5. ročníku řešit např. vypočítáním časů př́ijezdu obou objektů do cílového místa a jejich porovnání, dále pomocí obrázku nebo kombinací obojího; úloha je číselně přivětivá, lze ji vyřešit vhledem, úvahou. Na rozdíl od předchozích úloha nevyžaduje číselnou odpověd', žáci mají odpovědět ano/ne. Abychom eliminovali tipování, požadujeme po žácích zdůvodnění.

Atraktivní varianta (U3a): Ve dvě hodiny přišel Robin Prchal ze školy, položil na stůl oznámeni o ředitelské důtce a začal prchat. Prchal rychlostí 10 kilometrů v hodině. O čtvrt hodiny později si oznámení přečetl jeho otec, zrudl, nasedl na tř́kolku a začal syna stíhat rychlosti 15 kilometrů v hodině. Stihne se Robin schovat u spolužačky Zatloukalové, která bydli 5 kilometrů od Prchalových, dř́ve, než ho dožene otec? Svou odpověd’ zdůvodni. ${ }^{6}$

Neutrální varianta (U3n): Ve dvě hodiny vyjel traktor naložený senem po silnici z Adamova do Beranova. Jel rychlosti 10 kilometrü v hodině. O čtvrt hodiny později vyrazil z Adamova po stejné silnici cyklista rychlostí 15 kilometrů v hodině. Stihne traktor dojet do Beranova, který je vzdálený 5 kilometrư, dřive, než ho dožene cyklista? Svou odpověd zdůvodni.

Očekávali jsme, že varianty s atraktivním kontextem budou mít obecně vyšší procento řešitelů a také vyšší procento úspěšných řešitelů. Na základě prostudované literatury a pilotní studie jsme předpokládali, že atraktivní kontext bude žáky motivovat $\mathrm{k}$ řešení úlohy a vybaví je větší rezistencí vůči nezdaru. Také jsme očekávali, že u atraktivních variant budou žáci méně používat povrchové řešitelské strategie.

U Úlohy 1 jsme navíc předpokládali, že žáci budou úlohu vzhledem $\mathrm{k}$ její délce vynechávat častěji než jiné úlohy. Považovali jsme za pravděpodobné, že variantu Úlohy 2 se sci-fi kontextem budou častěji řešit chlapci než děvčata a že budou v řešení úspěšnější. Na základě výsledků výzkumu (Zohar \& Gershikov, 2008) lze očekávat, že varianta s kontextem narozeninové oslavy bude mírně lépe řešena dívkami. V Úloze 3 jsme předpokládali obecně nejnižší úspěšnost, nebot se žáci s úlohami o pohybu nemuseli v 5 . ročníku ještě setkat. Atraktivní varianta této úlohy má potenciál oslovit univerzální lidské potřeby (viz odd. 2.5), mohla by tedy vést $\mathrm{k}$ většímu rozdílu $\mathrm{v}$ úspěšnosti mezi variantami než předchozí dvojice úloh.

\subsection{Sběr a analýza dat kvantitativní části}

Testování probíhalo od prosince 2017 do dubna 2018 v rámci běžné výuky za asistence třídních učitelů a členů řešitelského týmu či poučených spolupracovníků. Žáci byli jednotně instruováni ${ }^{7}$ a povzbuzeni ke snaze o nejlepší výkon, zároveň ale nestresováni hrozbou známky nebo jiného hodnocení. V rámci testování byli požádáni o zápis postupů svých řešení a př́ipadné komentáře $\mathrm{k}$ úlohám, se kterými si nevědí rady. Nebylo povoleno používat kalkulačky a gumovat. Na vyřešení testu měli žáci 45 minut, většinou ale stihli test odevzdat před uplynutím tohoto limitu (15-30 minut). O průběhu testovaní v každé tř́dě byl zadavatelem testu sepsán protokol, v němž se mj. evidovaly všechny otázky žáků během testování

\footnotetext{
${ }^{6}$ Text původní úlohy: „Robin přišel v 10 hodin ze školy, položil na stůl vysvědčení a počal prchat směrem na jihozápad rychlostí $10 \mathrm{~km} / \mathrm{h}$. O 2 hodiny později si vysvědčení přečetl otec, nasedl na trojkolku a začal syna stíhat rychlostí $20 \mathrm{~km} / \mathrm{h}$. Za jak dlouho a jak daleko od domu dostane syn výprask (nebo pochvalu)?"

(https://2zskolin.cz/wp-content/uploads/2019/02/plus06_zadani.pdf)

${ }^{7}$ Instrukce $\mathrm{k}$ testu byly následující: Děkujeme, že se účastníš našeho testování. Pro tvé učitele i pro nás je důležité vědět, co žákům v matematice jde a co ne. Pomůže to i tvưrcům učebnic. Úlohy řeš bez použití kalkulačky. Zapisuj i postup řešení a nezapomeň na slovní odpověd. Pokud se ti řešení nevejde na tento papír, požádej učitele o další. Úlohy řeš v libovolném pořadí. Pokud uděláš chybu, negumuj, jen škrtni chybné řešení jednou čarou. Nezapomeň otočit papír na druhou stranu, kde jsou další úlohy. Nepoužívej gumovací pero.
} 
i doslovné odpovědi zadavatele. ${ }^{8}$ Zadavatel měl též za úkol hlídat s pomocí třídního učitele dobré pracovní klima (kázeň) a zabraňovat žákům v opisování.

Bodové hodnocení úloh bylo zdrojem kvantitativních výzkumných dat. Pro vyhodnocení úspěšnosti řešení úloh bylo zvoleno čtyřstupňové hodnocení: 0 bodů za neřešenou úlohu nebo za chybný výsledek bez náznaku správného výpočtu, 1 bod za částečně správné řešení či krok vedoucí dobrým směrem, 2 body za správné řešení s drobnou chybou (numerickou nebo způsobenou přehlédnutím), 3 body za správné řešení. ${ }^{9}$ Body byly zapisovány do tabulky společně s dalšími informacemi potřebnými pro kvalitativní analýzu žákovských řešení. Hodnotitelé, proškolení studenti PedF UK a řešitelé projektu, postupovali podle společného manuálu, v případě úloh použitých v této studii bylo hodnocení provedeno nezávisle znovu autorkou tohoto textu a porovnáno s předchozím hodnocením. Bodové hodnocení bylo následně převedeno do dichotomického skórování: hodnocení 0 bodů a 1 bod jako 0 bodi̊, hodnocení 2 body a 3 body jako 1 bod. Za správná řešení tak byla považována i řešení s numerickou chybou, nebot ta nesouvisí se správností porozumění úloze.

Na základě bodového zisku byla za použití klasické teorie testů vypočítána průměrná úspěšnost $P=$ $=\frac{\bar{x}}{\max }$ (kde $\bar{x}$ znamená průměrný počet bodů v úloze a max dosažitelné maximum). Pro hlubší analýzu statistických charakteristik úloh (obtížnost a diskriminace) byl použit dvouparametrický logistický model Item Response Theory (Lord, 1980): $P_{i j}=\frac{1}{1+\mathrm{e}^{-a_{i}\left(\theta_{j}-b_{i}\right)}}$, kde $P_{i j}$ představuje pravděpodobnost, se kterou žák $j$ s latentní schopností $\Theta_{j}$ vyřeší správně úlohu $i$. Parametr $a_{i}$ charakterizuje diskriminační schopnost úlohy a $b_{i}$ její obtížnost. Rozsah latentní schopnosti žáka $\Theta$ byl stanoven na $-3<\Theta<3$, kde hodnoty kolem nuly představují průměrného žáka, hodnoty blížící se k 3 žáka s vyšší latentní schopností a hodnoty blížící se $\mathrm{k}-3$ žáka s nižší latentní schopností (vodorovná osa na obrázku 1). Na stejném kontinuu se nachází obtížnost úlohy (parametr $b$ ). Čím vyšší je hodnota $b$, tím obtížnější úloha pro žáky je, což lze také vyčíst z polohy křivky (obr. 1). Čím více je křivka posunutá ve vodorovném směru doprava, tím větši je obtížnost úlohy, kterou představuje. Diskriminaci úlohy (parametr $a$ ) lze vyčíst ze sklonu křivky (obr. 1), čím strmější je křivka, tím lepší diskriminační schopnost úloha má. Nižší diskriminace se promítá do chyby v určení obtížnosti úlohy (s.e. (b)). Při prezentaci výsledků uvádíme věcné rozdíly $\left|a_{i}-a_{j}\right|$ a $\left|b_{i}-b_{j}\right|$ a dosažené hladiny významnosti testu (v závorce).

\subsection{Sběr a analýza dat kvalitativní části}

Písemná žákovská řešení byla analyzována z hlediska řešitelských postupů a chyb. Před vyhodnocováním testových sešitů byly pro každou úlohu vytipovány očekávatelné řešitelské postupy a chyby. Postupy byly dále rozloženy do jednotlivých kroků (ukázka viz Př́loha 1). Hodnotitelé na základě podrobného manuálu zaznamenávali do tabulky k řešení každého žáka výskyt těchto postupových kroků a chyb, evidovány byly také další jevy provázející řešení (např. př́itomnost a typ legendy, použití tabulky, přítomnost odpovědi aj.). Striktně oddělovány byly strategie či chyby s nejasným nebo nejednoznačným původem a pro následnou analýzu nebyly použity. Vyskytla-li se v řešení žáka chyba nebo řešitelská strategie neodpovídající žádné položce v manuálu, byla označena jako jiná a po vyhodnocení všech př́slušných testů a zjištění její frekvence bud' přidána do manuálu a zpětně dohledána a označena ve všech žákovských řešeních nebo ponechána a analyzována zvlášt v rámci kategorie jiná. K tomu sloužila další kolonka v tabulce, která evidovala číselný výsledek úlohy, k němuž žák dospěl (pro rychlou orientaci a vzájemné porovnávání řešení se stejnými chybnými výsledky, a tedy potenciálně stejnými chybnými postupy), a stručný záznam jeho řešitelského postupu. Při nejasnostech byly žákovské práce, jejich skeny, konzultovány alespoň dvěma hodnotiteli. Také v tomto případě bylo hodnocení a evidence strategií a chyb provedeno kompletně dvakrát, nejprve proškoleným studentem či členem řešitelského týmu a později autorkou tohoto článku.

Před vlastní kvalitativní analýzou byla provedena frekvenční analýza nalezených chyb a řešitelských postupů, pozornost byla věnovaná jak chybám s vysokým, tak s nízkým nebo dokonce ojedinělým výskytem. ${ }^{10}$ Následný rozbor chyb a postupů se zakládal pouze na písemných řešeních žáků, rozhovory se

\footnotetext{
${ }^{8}$ Způsob vhodné (a napříč třídami konzistentní) reakce na předpokládané dotazy žáků byl rovněž součástí poučení zadavatelů.

${ }^{9}$ U Úlohy 3 dostalo žákovské řešení 3 body, pokud kromě správné odpovědi ( „ano, stihne“) obsahovalo i záznam výpočtu nebo zdůvodnění. Dva body získalo řešení s logicky správným zaznamenaným postupem či zdůvodněním, ale chybným závěrem („nestihne, dorazí nastejno“) zapříčiněným numerickou chybou nebo menší chybou v úvaze. Jeden bod získalo a) řešení obsahující správnou odpověd', ale nedostatečné, chybné nebo žádné zdo̊vodnění, b) řešení obsahující chybnou odpověd' („nestihne, dorazí nastejno“), ale nějaký postupový krok dobrým směrem. Za chybné odpovědi („nestihne, dorazí nastejno“) s nesprávným nebo žádným zdůvodněním bylo 0 bodů. Abychom zajistili větší objektivitu při posuzování správnosti argumentů u této úlohy, žákovská řešení vyhodnocovali dva na sobě nezávislí hodnotitelé, shoda byla téměř stoprocentní. Za dostatečné argumenty jsme považovali například: „Robin/traktor dorazí o 5 minut dříve než otec/cyklista“, „Robin/traktor potřebuje na překonání vzdálenosti 30 minut, otec/cyklista 20 minut, ale vyráží s 15 minutovým zpožděním“ apod.

${ }^{10}$ Občas tato řešení poukázala na zajímavý jev, nebo přispěla k objasnění řešení jiných žáků.
} 
žáky nebyly v této fázi prováděny. ${ }^{11}$ Naše interpretace jsou tedy snahou o rekonstrukci pravděpodobného procesu řešení úlohy žákem, ${ }^{12}$ a nemusí být proto vždy přesným odrazem jeho skutečného uvažování. Výsledky těchto analýz je tedy třeba vnímat jako orientační.

\section{Výsledky}

\section{1 Úloha 1: Lichožrouti}

Tabulka 1 a grafy na obrázku 1 ukazují, že při řešení varianty U1a (s lichožrouty) byli žáci skutečně mírně úspěšnější než u varianty U1n. Lepších výsledků dosahovali žáci všech sledovaných skupin - žáci se střední, nižší i vyšší latentní schopností, rozdíly však ani v jedné skupině nedosáhly statistické významnosti. Úloha byla pro žáky daného věku přiměřeně obtížná (průměrná úspěšnost $55 \%$ ), obě varianty dobře diskriminovaly. Z celkového počtu 141 žáků jsme pouze u 10 z nich nenašli pod textem úlohy žádný náznak řešení. Tyto počty u obou variant byly vyrovnané.

Tab. 1: Výsledky statistických testů rozdílů v obtížnosti a diskriminaci variant Úlohy 1 (5. ročník)

\begin{tabular}{|c|c|c|c|c|c|c|c|c|}
\hline varianta & $N$ & úspěšnost & $a$ & s. e. $(a)$ & $b$ & s. e. $(b)$ & $\begin{array}{l}\text { rozdíly hodnot } \\
\text { diskriminace } a^{*}\end{array}$ & $\begin{array}{c}\text { rozdíly hodnot } \\
\text { obtížnosti } b^{*}\end{array}$ \\
\hline atraktivní & 70 & $59 \%$ & 1,40 & 0,41 & $-0,49$ & 0,22 & \multirow{2}{*}{$0,1(0,867)$} & \multirow{2}{*}{$0,4(0,181)$} \\
\hline neutrální & 71 & $52 \%$ & 1,50 & 0,43 & $-0,09$ & 0,20 & & \\
\hline
\end{tabular}

*V závorce jsou hodnoty $p$.

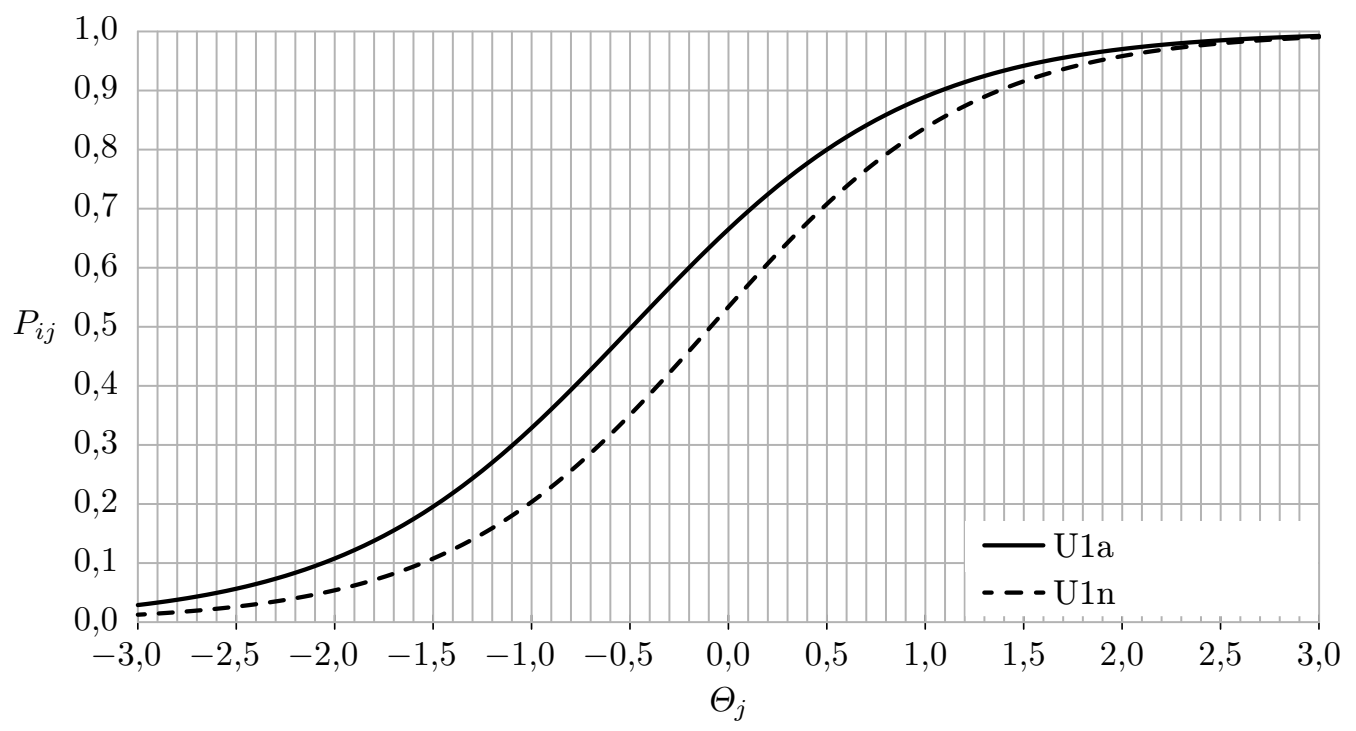

Obr. 1: IRT grafy pro varianty Úlohy 1

Pestrost chyb byla v této úloze ve srovnání s jinými testovanými úlohami poměrně velká. Zajímavé je, že úloha obecně nesváděla $\mathrm{k}$ používání povrchových strategii tak často, jako tomu bylo u jiných úloh v rámci výzkumu (Vondrová et al., 2019). Pouze u tř́ žáků jsme zaznamenali tendenci vytvořit matematický model (výpočet) bez vytvoření situačního modelu. Další dva žáci provedli kroky v opačném pořadí (nejprve odečetli 20 minut a pak teprve dělili), což také ukazuje na chybně vytvořenou představu o situaci. Na obrázku 2 je vidět řešení Matouše (varianta U1n), který byl k přehození pořadí kroků doveden okolnostmi, přestože jeho představa o situaci byla v počátku správná. Pět a pưl hodiny si přečetl jako pětatřicet minut, které se správně pokusil vydělit dvěma (škrtnutý výpočet v levé části obrázku), ale protože nevycházelo celé číslo, rozhodl se prohodit kroky a nejprve odečíst 20 (škrtnutý výpočet uprostřed). Tím se ale problém nevyřešil, tak zřejmě rezignoval na svůj původní řešitelský plán opřený o dobré porozumění úloze, což prozrazují šipky v legendě, z nichž lze vyčíst, že polovinu vztahuje správně k číslu 35, nikoliv k 20, a vydělil čísla, která dělit šla (20:2), a výsledek odečetl od 35.

\footnotetext{
${ }^{11}$ Testování velkého vzorku žáků na několika školách v jednom okamžiku neumožňovalo provádět rozhovory s žáky bezprostředně po testování (vyhodnocování úloh probíhalo obvykle více než měsíc), ani sledovat každého žáka jednotlivě při řešení úloh a doptávat se na potřebné informace.

${ }^{12}$ Analyzovány byly i škrtnuté či gumované části řešení a další projevy naznačující potenciální průběh řešitelského procesu (např́klad podtrhávání či kroužkování v textu úlohy, náčrtky, ilustrace aj.).
} 


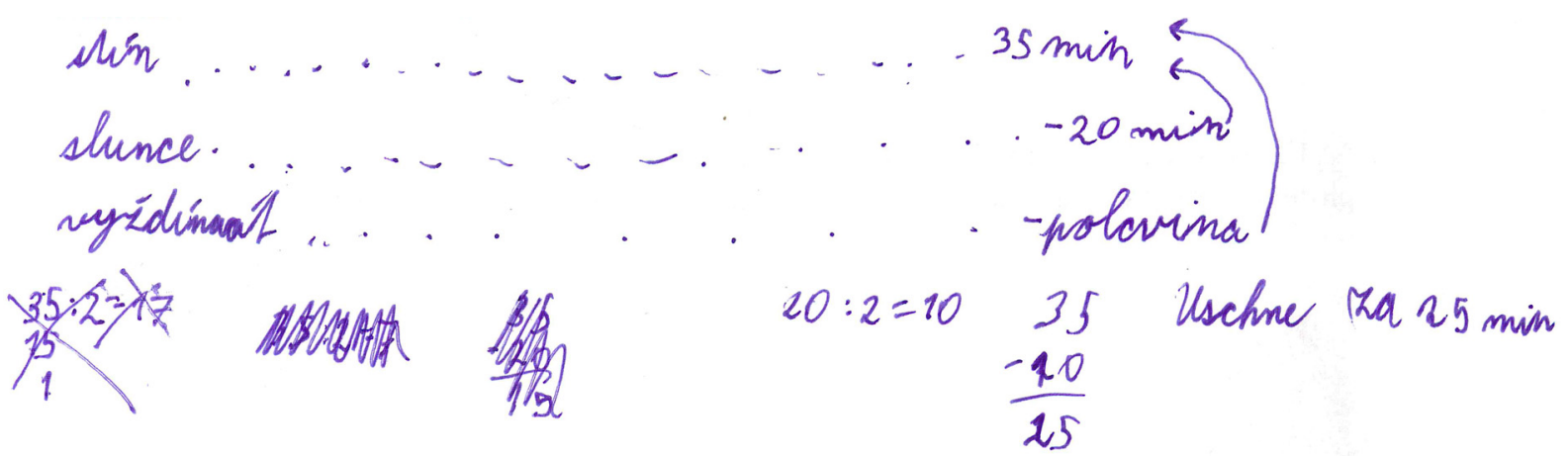

Obr. 2: К̌ešení Matouše (varianta U1n)

Největším úskalím byl pro žáky první krok, tedy vypočítat polovinu z 5 a pưl hodiny. Častým výsledkem tohoto kroku bylo 2 h 30 minut (2 a půl hodiny) nebo 2 h 15 minut (přehled a četnost jednotlivých chyb ukazuje tab. 2). V prvním př́padě žáci pravděpodobně rozdělili jen 5 hodin a na půlhodinu zapomněli, v druhém př́padě naopak rozdělili půlhodinu po 15 minutách, ale při rozdělení 5 hodin pracovali jen s celou částí a na desetinnou zapomněli. Jev, který často doprovázel tuto chybu, je vidět na řešení Marka (obr. 3). Údaj 5 a půl hodiny správně zapsal v jazyce desetinných čísel jako $5,50^{13}$ a při dělení dvěma udělal výše popisovanou chybu. Se získaným výsledkem již dále nepracoval jako s desetinným číslem, ale vrátil se do jazyka hodin, a tak od desetinné části 0,25 odečetl 20 minut. Že žák není v režimu desetinných čísel, prozrazuje také podoba výsledku tohoto odčítání, které není zapsáno 2,05 , ale 2,5 . To ukazuje na jednu z miskoncepcí, které mohou provázet žáky při ranných pokusech o používání desetinných čísel. Podobné projevy chybného chápání desetinných čísel a problémy s operacemi v šedesátkové soustavě byly $\mathrm{v}$ řešeních žáků poměrně časté. Výjimkou nebyly ani chybné převody hodin na minuty, např. $5 \mathrm{~h}$ a 30 minut $=530$ minut (v tab. 2 chyba hybridní zacházení s jednotkami času).

Tab. 2: Porovnání absolutní četnosti výskytu chyb v obou variantách Úlohy $1^{*}$

\begin{tabular}{lrrr}
\hline \multirow{2}{*}{ popis chyby } & kontext & atraktivní & neutrální \\
\cline { 2 - 4 } & $N$ & 70 & 71 \\
\hline problém s vytvořením situačního modelu & 3 & 8 \\
\hline obrácení pořadí výpočetních kroků & 1 & 1 \\
\hline chyba v 1. kroku (půlení 5 a půl hodiny) & 21 & 20 \\
\hline hybridní zacházení s jednotkami času & 10 & 9 \\
\hline chybné čtení 5 a půl jako „pětatřicet“ & 1 & 2 \\
\hline chybu nelze určit, postup chybí nebo je nejasný & 12 & 11 \\
\hline
\end{tabular}

*Obě varianty jsou zastoupeny téměř stejným počtem žáků, uvádíme tedy absolutní četnost. Někteři žáci měli více chyb najednou, uvádíme výskyt všech chyb.

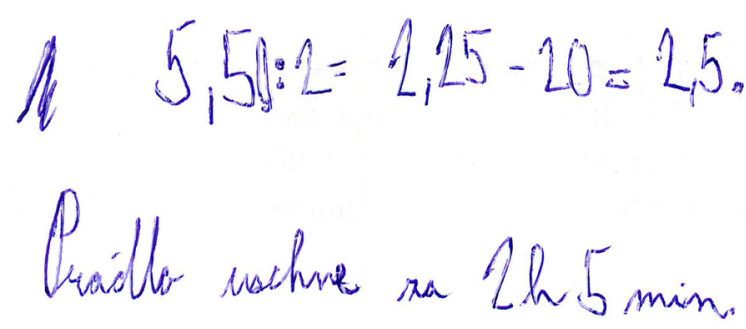

Obr. 3: ̌̌ešení Marka (varianta U1n)

Analýza chyb neukázala, že by jedna z variant Úlohy 1 sváděla k nějaké specifické chybě. Při dodatečné analýze zadání obou variant jsme identifikovali jeden potenciálně důležitý rozdíl, a sice že v neutrální variantě je v úvodní části použito slovo stín, které by mohlo být žáky vnímáno jako opozitum ke slunci a budit dojem, že nese nějaký matematický význam. Tím by se úloha mohla komplikovat. U žádného žáka jsme nenašli řešení, které by zmíněný efekt tohoto slova potvrzovalo, ${ }^{14}$ ale zároveň jej nemůžeme zcela vyloučit. Závěr tedy vyslovujeme s opatrností: mírně vyšší úspěšnost varianty U1a mohla být způsobena kontextem.

\footnotetext{
${ }^{13}$ Nula za číslem 5,5 se jeví jako dodatečně připsaná. Domníváme se, že žáka k tomu dovedla právě až potřeba dělit liché číslo dvěma, z nedělitelného čísla 5 tak udělal číslo dělitelné (50).

${ }^{14}$ Občas se vyskytlo v legendě, jak je patrné i z obr. 2.
} 


\section{2 Úloha 2: Hvězdné impérium ${ }^{15}$}

Výsledky, které shrnuje tabulka 3, ukazují, že mezi variantami úlohy byl tentokrát výraznější rozdíl. Varianta U2n byla statisticky významně méně obtížná než varianta s atraktivním kontextem U2a. Úspěšnost žáků jednotlivých výkonnostních skupin jsou dobře čitelné z grafů (obr. 4). Varianta s neutrálním kontextem U2n byla snadno řešitelná pro žáky s vyšší a střední latentní schopností, varianta U2a byla často náročná i pro žáky s vyšší latentní schopností.

Tab. 3: Výsledky statistických testů rozdílů v obtížnosti a diskriminaci variant Úlohy 2 (5. ročník) (Vondrová et al., 2019, s. 77)

\begin{tabular}{lcccccccc}
\hline varianta & $N$ & úspěšnost & $a$ & s.e. $(a)$ & $b$ & s. e. $(b)$ & $\begin{array}{c}\text { rozdíly hodnot } \\
\text { diskriminace } a^{*}\end{array}$ & $\begin{array}{c}\text { rozdíly hodnot } \\
\text { obtížnosti } b^{*}\end{array}$ \\
\hline atraktivní & 161 & $24 \%$ & 1,18 & 0,31 & 1,21 & 0,29 & \multirow{2}{*}{$0,23(0,576)$} & $1,55(\mathbf{0 , 0 0 0})$ \\
\hline neutrální & 177 & $58 \%$ & 1,41 & 0,27 & $-0,34$ & 0,14 & & 1,23 \\
\hline
\end{tabular}

*V závorce jsou hodnoty $p$, statisticky významný rozdíl pro $p<0,05$ je tučně.

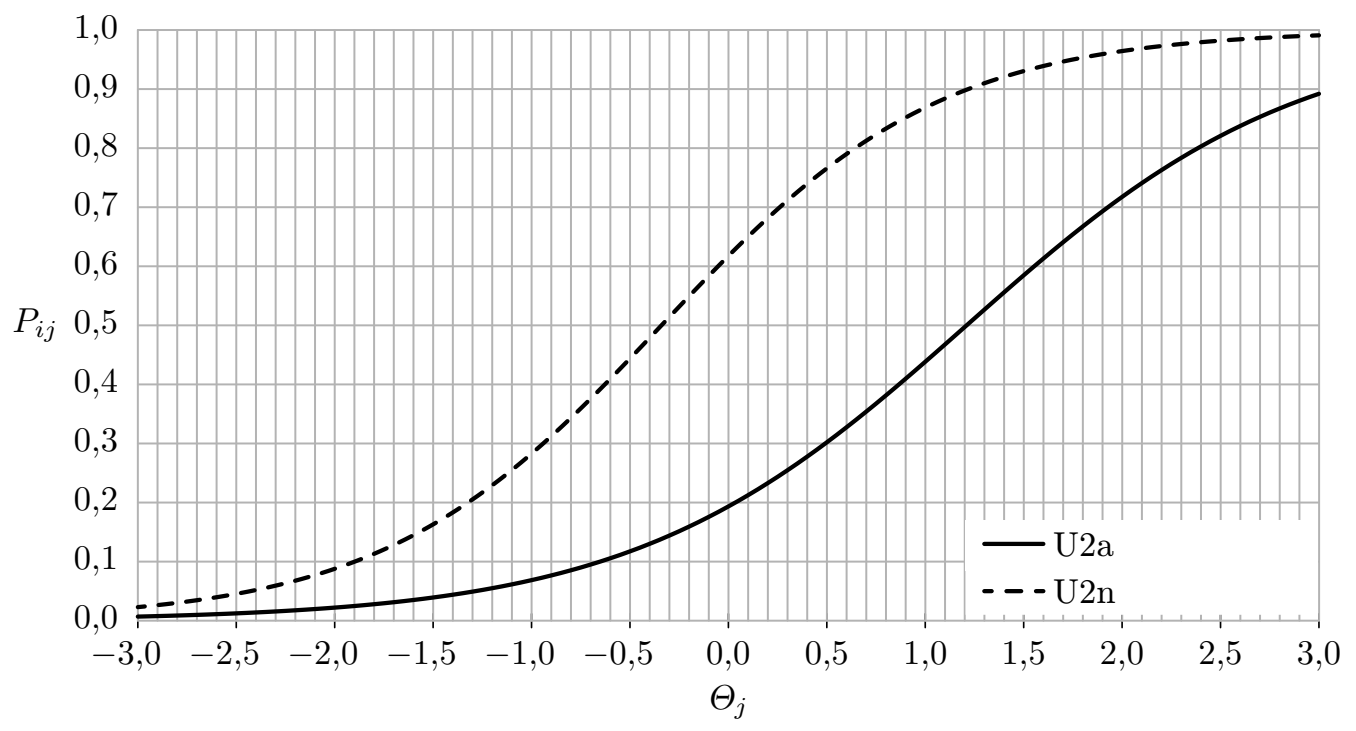

Obr. 4: IRT grafy pro obě varianty Úlohy 2 (5. ročník) (Vondrová et al., 2019, s. 78)

Tab. 4 ukazuje, že v souladu s naším očekáváním byla varianta U2a častěji vynechávána dívkami a že mezi úspěšnými řešiteli této varianty bylo vyšší procento chlapců než dívek (rozdíl 5 p. b.). Rozdíly však nebyly velké. Překvapivé je, že lépe dopadli chlapci i při řešení druhé varianty U2n s neutrálním, resp. dívčím kontextem, ve které dosáhli zhruba o 7 p. b. lepšího výsledku než děvčata. Co se týká ochoty žáků začít úlohu řešit, zde byly počty chlapců a dívek vyrovnané a náš předpoklad se nepotvrdil.

Tab. 4: Relativní četnost bodového zisku chlapců vs. děvčat v obou variantách Úlohy 2 (5. ročník)

\begin{tabular}{|c|c|c|c|c|c|c|c|c|c|c|}
\hline varianta & ročník & & $N$ & neřešeno & 0 & 1 & 2 & 3 & $0+1$ & $\overline{2+3}$ \\
\hline \multirow{2}{*}{$\begin{array}{c}\text { atraktivní } \\
(\mathrm{U} 2 \mathrm{a})\end{array}$} & \multirow{2}{*}{5} & chlapci & 62 & $15 \%$ & $24 \%$ & $34 \%$ & $0 \%$ & $27 \%$ & $73 \%$ & $27 \%$ \\
\hline & & dívky & 99 & $19 \%$ & $30 \%$ & $28 \%$ & $4 \%$ & $18 \%$ & $78 \%$ & $22 \%$ \\
\hline \multirow{2}{*}{$\begin{array}{c}\text { neutrální } \\
(\mathrm{U} 2 \mathrm{n})\end{array}$} & \multirow{2}{*}{5} & chlapci & 94 & $5 \%$ & $11 \%$ & $23 \%$ & $2 \%$ & $59 \%$ & $39 \%$ & $61 \%$ \\
\hline & & dívky & 83 & $4 \%$ & $16 \%$ & $27 \%$ & $8 \%$ & $46 \%$ & $46 \%$ & $54 \%$ \\
\hline
\end{tabular}

U této úlohy máme $\mathrm{k}$ dispozici i výsledky žáků 6 . ročníku $(n=291)$. Jak je vidět z grafů na obr. 5 , jsou velmi podobné. Úloha je celkově úspěšnější než v 5 . ročníku, což lze vzhledem k vyššímu věku předpokládat (tab. 5). Podobný tvar křivek naznačuje, že také pravděpodobnost správného vyřešení narostla u všech výkonnostních skupin žáků rovnoměrně. Varianta U2a se jeví jako úloha vhodná k diagnostickým účelům pro tuto věkovou kategorii, nebot je její křivka dostatečně strmá (srov. s křivkou U2a na obr. 4).

Tab. 6 nabízí přehled rozdílů v bodovém zisku chlapců a dívek. Za povšimnutí stojí, že v 5. i 6 . ročníku byly rozdíly v úspěšnosti chlapců a dívek menší v úloze se sci-fi kontextem (5. ročník 5 p. b., 6 . ročník 8 p. b.) než v úloze s neutrálním kontextem (5. ročník 7 p. b., 6. ročník 13 p. b.).

${ }^{15}$ Úloha byla podrobněji rozebrána také v (Vondrová et al., 2019, s. 77-78). 


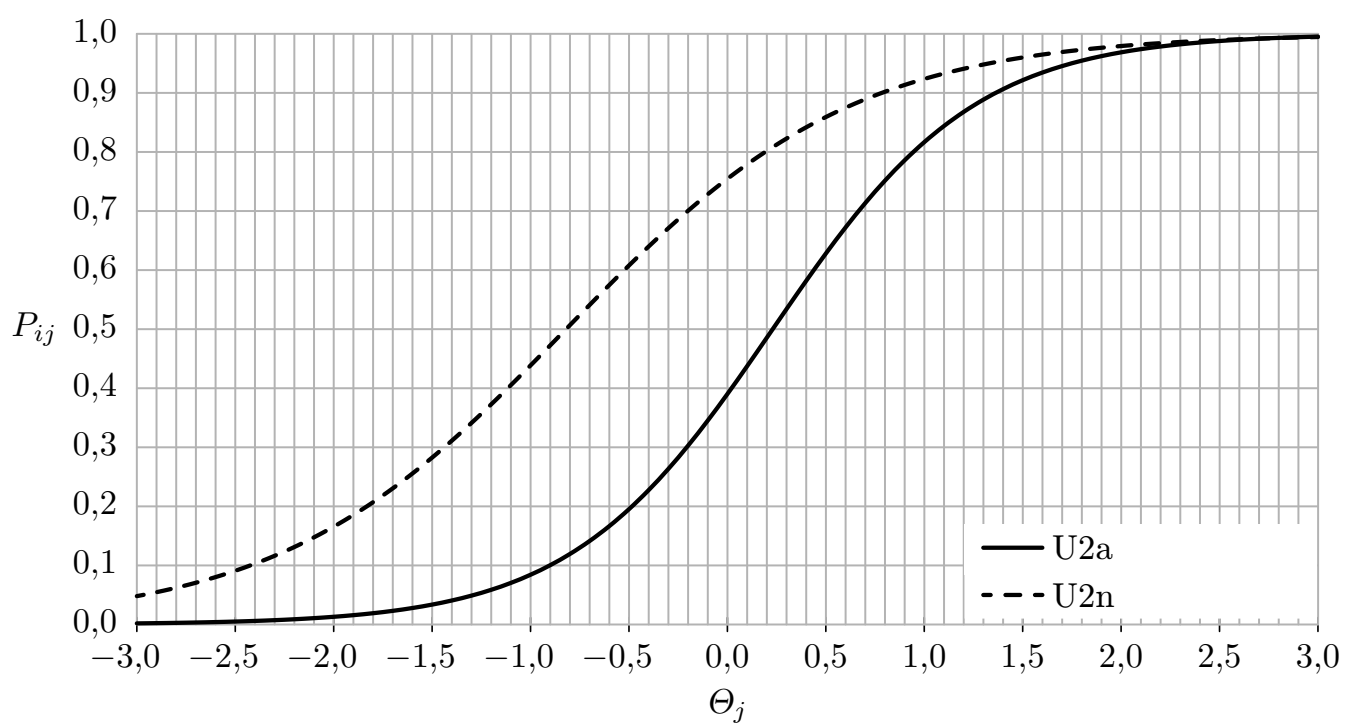

Obr. 5: IRT grafy pro obě varianty Úlohy 2 (6. ročník) (Vondrová et al., 2019, s. 78)

Tab. 5: Výsledky statistických testů rozdílů v obtížnosti a diskriminaci variant Úlohy 2 (6. ročník) (Vondrová et al., 2019, s. 77)

\begin{tabular}{|c|c|c|c|c|c|c|c|c|}
\hline varianta & $N$ & úspěšnost & $a$ & s. e. $(a)$ & $b$ & s.e. $(b)$ & $\begin{array}{l}\text { rozdíly hodnot } \\
\text { diskriminace } a^{*}\end{array}$ & $\begin{array}{l}\text { rozdíly hodnot } \\
\text { obtížnosti } b^{*}\end{array}$ \\
\hline$\overline{\text { atraktivní }}$ & 150 & $41 \%$ & 1,94 & 0,41 & 0,23 & 0,12 & \multirow{2}{*}{$0,57(0,274)$} & \multirow{2}{*}{$1,05(\mathbf{0 , 0 0 0})$} \\
\hline neutrální & 141 & $72 \%$ & 1,37 & 0,32 & $-0,82$ & 0,20 & & \\
\hline
\end{tabular}

*V závorce jsou hodnoty $p$, statisticky významný rozdíl pro $p<0,05$ je tučně.

Tab. 6: Relativní četnost bodového zisku chlapců vs. děvčat v obou variantách Úlohy 2 (6. ročník)

\begin{tabular}{|c|c|c|c|c|c|c|c|c|c|c|}
\hline varianta & roč. & & $N$ & neřešeno & 0 & 1 & 2 & 3 & $0+1$ & $2+3$ \\
\hline \multirow{2}{*}{$\begin{array}{c}\text { atraktivní } \\
\text { (U2a) }\end{array}$} & \multirow{2}{*}{6} & chlapci & 68 & $10 \%$ & $24 \%$ & $21 \%$ & $6 \%$ & $40 \%$ & $54 \%$ & $46 \%$ \\
\hline & & dívky & 82 & $22 \%$ & $18 \%$ & $22 \%$ & $4 \%$ & $34 \%$ & $62 \%$ & $38 \%$ \\
\hline \multirow{2}{*}{$\begin{array}{c}\text { neutrální } \\
(\mathrm{U} 2 \mathrm{n})\end{array}$} & \multirow[b]{2}{*}{6} & chlapci & 78 & $1 \%$ & $3 \%$ & $21 \%$ & $12 \%$ & $64 \%$ & $24 \%$ & $76 \%$ \\
\hline & & dívky & 63 & $5 \%$ & $8 \%$ & $24 \%$ & $8 \%$ & $56 \%$ & $37 \%$ & $63 \%$ \\
\hline
\end{tabular}

Při analýze písemných řešení žáků jsme zjistili, že nejčastější chyba napříč variantami i ročníky plynula z kumulativní povahy matematického modelu úlohy (viz tab. 7). Žáci si často neuvědomovali, že výsledky průběžných kroků je třeba započítat do celkového počtu - nezapočítali tak fauny zasažené korvetami a fregatou, resp. kamarádky Nely a Bely, ale sečetli pouze fauny zasažené křižníkem a fauny stažené z útoku, resp. kamarádky Lei a členy rodiny. Dvě nejčastější chyby tohoto typu jsou vidět v řešení Marie a Jana (obr. 6 a 7). Relativně častým vynechaným číslem ve výpočtu bylo také 11 (fauni, kteří se z boje stáhli, resp. členové rodiny trojčat), přičemž za povšimnutí stojí fakt, že zatímco tuto chybu dělali žáci 5. ročníku častěji u neutrální varianty, žáci 6 . ročníku tak činili výrazně častěji u atraktivní varianty. Nemáme pro to žádné vysvětlení.

Tab. 7: Porovnání relativní četnosti výskytu chyb v obou variantách Úlohy 2 (5. a 6. ročník) (\%)*

\begin{tabular}{|c|c|c|c|c|c|c|}
\hline \multirow{3}{*}{ popis chyby } & varianta & atraktivní & neutrální & atraktivní & neutrální & celkem \\
\hline & roč. & 5 & 5 & 6 & 6 & 5,6 \\
\hline & $N$ & 161 & 177 & 150 & 141 & 629 \\
\hline chyba typu „Marie“ & & $17 \%$ & $17 \%$ & $11 \%$ & $9 \%$ & $14 \%$ \\
\hline chyba typu „Jan“ & & $18 \%$ & $14 \%$ & $8 \%$ & $7 \%$ & $12 \%$ \\
\hline vynechání 11 & & $1 \%$ & $6 \%$ & $8 \%$ & $1 \%$ & $4 \%$ \\
\hline povrchová strategie & & $13 \%$ & $3 \%$ & $9 \%$ & $2 \%$ & $7 \%$ \\
\hline záměna „o 4 více“ za „4x více“ & & $3 \%$ & $3 \%$ & $1 \%$ & $0 \%$ & $2 \%$ \\
\hline odečtení 11 & & $1 \%$ & $1 \%$ & $1 \%$ & $0 \%$ & $1 \%$ \\
\hline připočítání Nely, Bely a Lei & & $0 \%$ & $1 \%$ & $0 \%$ & $1 \%$ & $0 \%$ \\
\hline chyba numerická, chyba v algoritmu & & $4 \%$ & $9 \%$ & $5 \%$ & $9 \%$ & $7 \%$ \\
\hline jiná chyba & & $6 \%$ & $5 \%$ & $11 \%$ & $4 \%$ & $7 \%$ \\
\hline
\end{tabular}

*Někteří žáci měli více chyb najednou, uvádíme výskyt všech chyb. Tučně jsou vyznačeny rozdíly 5 p. b. a více. 


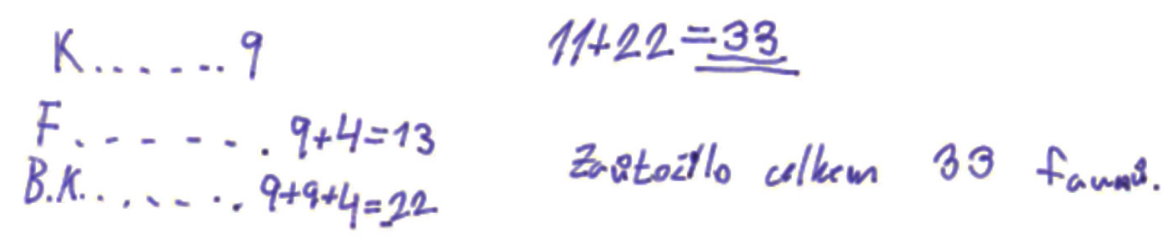

Obr. 6: ̌̌ešení Marie (varianta U2a)

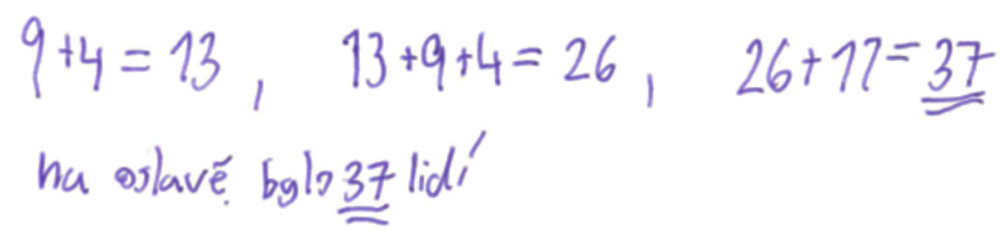

Obr. 7: ̌̌ešení Jana (varianta U2n)

Castým chybným postupem byl i součet jen čísel explicitně uvedených v zadání $(9,4$ a 11). Tato chyba je typickým projevem použití povrchové řešitelské strategie. Ve variantě s atraktivním kontextem U2a k ní docházelo čtyřikrát častěji než ve variantě U2n.

Nyní se podíváme na chyby specifické pro jeden či druhý kontext. Takovou chybou je např́klad odečtení 11 místo přičtení ve variantě U2a. Formulace „zbylých 11 faunů se stáhlo zpět na svou základnu“ mohla $\mathrm{v}$ představě žáků evokovat operaci odčítání, zatímco odpovídající část textu ve druhé variantě „pozvánku na oslavu dostalo také všech 11 členů rodiny“ je impulzem k přičítání. Když se však podíváme do tab. 7 na četnost této chyby, zjistíme, že i v tak velkém vzorku žáků $\mathrm{k}$ ní došlo pouze $\mathrm{v}$ jednotkách případů. Podobně nízkou frekvenci výskytu měla chyba přičtení Nely, Bely a Lei, kterou jsme očekávali naopak pouze u neutrální varianty. Otázkou, kterou lze očekávat, je „kolik je na oslavě lidí“, což by vedlo $\mathrm{k}$ přičtení trojčat.

Z analýzy chyb vyplývá, že žáci dělali nejfrekventovanější chyby v obou variantách téměř stejně. Rozdíl v úspěšnosti nebyl způsoben ani žádnou specifickou chybou, ke které by kontext jedné nebo druhé varianty vedl. Domníváme se, že nižší úspěšnost u varianty U2a by mohla být důsledkem kognitivního přetížení způsobeného drobnými odlišnostmi $\mathrm{v}$ textu a kontextu, které za společného působení tvořily větší překážku při snaze žáků vytvořit si situační model úlohy. Žáci tak častěji sahali k povrchovým strategiím, častěji chybovali jako Marie či Jan, nebot jejich pozornost odebralo vytváření představy o situaci popisované v úloze. Dodatečná analýza ${ }^{16}$ textu obou variant úlohy poukázala na řadu (nezamýšlených) rozdílů. Např́klad slova, která vyjadřují z hlediska matematiky stejnou akci, jsou v atraktivním kontextu vyjádřena třemi různými synonymy (zasáhnout, zneškodnit, zlikvidovat), zatímco v neutrálním kontextu jedním slovem (pozvat), což tvorbu situačního modelu zjednodušuje. Všechny rozdíly mezi zadáními, které jsme identifikovali, shrnuje tab. 8. Vyšší výskyt numerických chyb v úspěšnější variantě U2n, který bychom očekávali spíše u kognitivně náročnější varianty U2a, je dán tím, že chybný matematický model obtížnější varianty nedával tolik př́ležitostí k numerické chybě (výpočetní řetězec byl kratší).

\section{3 Úloha 3: Robin Prchal}

V souladu s naším očekáváním měla úloha celkově nízkou úspěšnost (okolo $20 \%$ ), přičemž vyšší úspěšnost měla varianta s atraktivním kontextem U3a (viz tab. 9). Rozdíly však nebyly statisticky významné. Varianta s neutrálním kontextem U3n diskriminovala výrazně lépe, jak je vidět na strmosti křivky (obr. 8). Žáci s nižší a střední latentní schopností v ní získávali obvykle hodnocení 0 nebo 1 bod, zatímco žáci s vyšší latentní schopností 2 nebo 3 body (tab. 10). Tvar druhé křivky naopak ukazuje, že varianta s atraktivním kontextem měla výrazně větší podíl žáků se střední a nízkou latentní schopností, kteří se o řešení pokusili a částečně v něm uspěli, tj. zaznamenali alespoň nějaký postupový krok dobrým směrem. Rozdíly v počtu úspěšných řešitelů ( 2 a 3 body) i rozdíly v počtu žáků, kteří úlohu zanechali bez náznaku řešení, jsou však nízké, takže z nich nelze vyvozovat závěry. ${ }^{17}$

\footnotetext{
${ }^{16}$ Provedena byla po vyhodnocení testování ve světle identifikovaných žákovských chyb a řešitelských postupů.

${ }^{17}$ Statistika je při nízkém počtu testovaných žáků citlivá na výkon jednotlivce.
} 
Tab. 8: Porovnání textu a kontextu atraktivní a neutrální varianty Úlohy 2

\begin{tabular}{|c|c|c|c|}
\hline$\overline{\text { vrstva }^{*}}$ & rozdíl & Hvězdné impérium (U2a) & Oslava narozenin (U2n) \\
\hline objektů & počítané objekty & $\begin{array}{l}\text { počítané objekty jsou dvojího druhu: } \\
\text { (1) zneškodnění fauni, (2) fauni, kteří } \\
\text { se stáhli na základnu }\end{array}$ & $\begin{array}{l}\text { počítanými objekty jsou } \\
\text { všichni, kteří byli pozváni }\end{array}$ \\
\hline$\overline{\text { př́běhu či situace }}$ & povaha situace & nepřátelský akt, konflikt & přátelský akt, oslava \\
\hline $\begin{array}{l}\text { matematického } \\
\text { modelu }\end{array}$ & $\begin{array}{l}\text { charakter aditivní } \\
\text { situace }\end{array}$ & $\begin{array}{l}\text { likvidování - ubírání lodí nepříteli; } \\
\text { použitá slovesa mohou evokovat } \\
\text { odčíánín }^{18}\end{array}$ & $\begin{array}{l}\text { přibývání pozvaných lidí na } \\
\text { oslavu; použité sloveso } \\
\text { evokuje sčítání }\end{array}$ \\
\hline \multirow{3}{*}{ jazyková } & slovní zásoba & $\begin{array}{l}\text { obsahuje cizí slova (fregata, stíhací } \\
\text { faun, křižník, impérium) a specifická } \\
\text { slovní spojení (obranná jednotka, } \\
\text { stáhnout se zpět na základnu) }\end{array}$ & neobsahuje žádná cizí slova \\
\hline & $\begin{array}{l}\text { slova označující } \\
\text { stejnou akci }\end{array}$ & $\begin{array}{l}\text { vyjádřena synonymy: zasáhnout, } \\
\text { zneškodnit, zlikvidovat }\end{array}$ & $\begin{array}{l}\text { vyjádřena stejným slovesem: } \\
\text { pozvat (Nela pozvala, Bela } \\
\text { pozvala, Lea pozvala) }\end{array}$ \\
\hline & $\begin{array}{l}\text { výčet upřesňujicí } \\
\text { hierarchii objektů }\end{array}$ & $\begin{array}{l}\text { výčet chybí; řešitel si musí domyslet, } \\
\text { že obranné jednotky jsou korvety, } \\
\text { fregata, bitevní křižník }\end{array}$ & $\begin{array}{l}\text { výčet je př́itomen v první } \\
\text { větě; řešitel ví, že trojčata } \\
\text { jsou Nela, Bela, Lea }\end{array}$ \\
\hline
\end{tabular}

*Rozdíly jsou zařazeny do vrstev dle (Hejný, 2003).

Tab. 9: Výsledky statistických testů rozdílů v obtížnosti a diskriminaci variant Úlohy 3 (5. ročník)

\begin{tabular}{|c|c|c|c|c|c|c|c|c|}
\hline varianta & $N$ & úspěšnost & $a$ & s. e. $(a)$ & $b$ & s. e. $(b)$ & $\begin{array}{l}\text { rozdíly hodnot } \\
\text { diskriminace } a^{*}\end{array}$ & $\begin{array}{l}\text { rozdíly hodnot } \\
\text { obtížnosti } b^{*}\end{array}$ \\
\hline atraktivní & 70 & $24 \%$ & 1,00 & 0,37 & 1,35 & 0,55 & \multirow{2}{*}{$1,7(0,427)$} & \multirow[b]{2}{*}{$0,32(0,588)$} \\
\hline neutrální & 74 & $16 \%$ & 2,70 & 2,10 & 1,03 & 0,21 & & \\
\hline
\end{tabular}

*V závorce jsou hodnoty $p$.

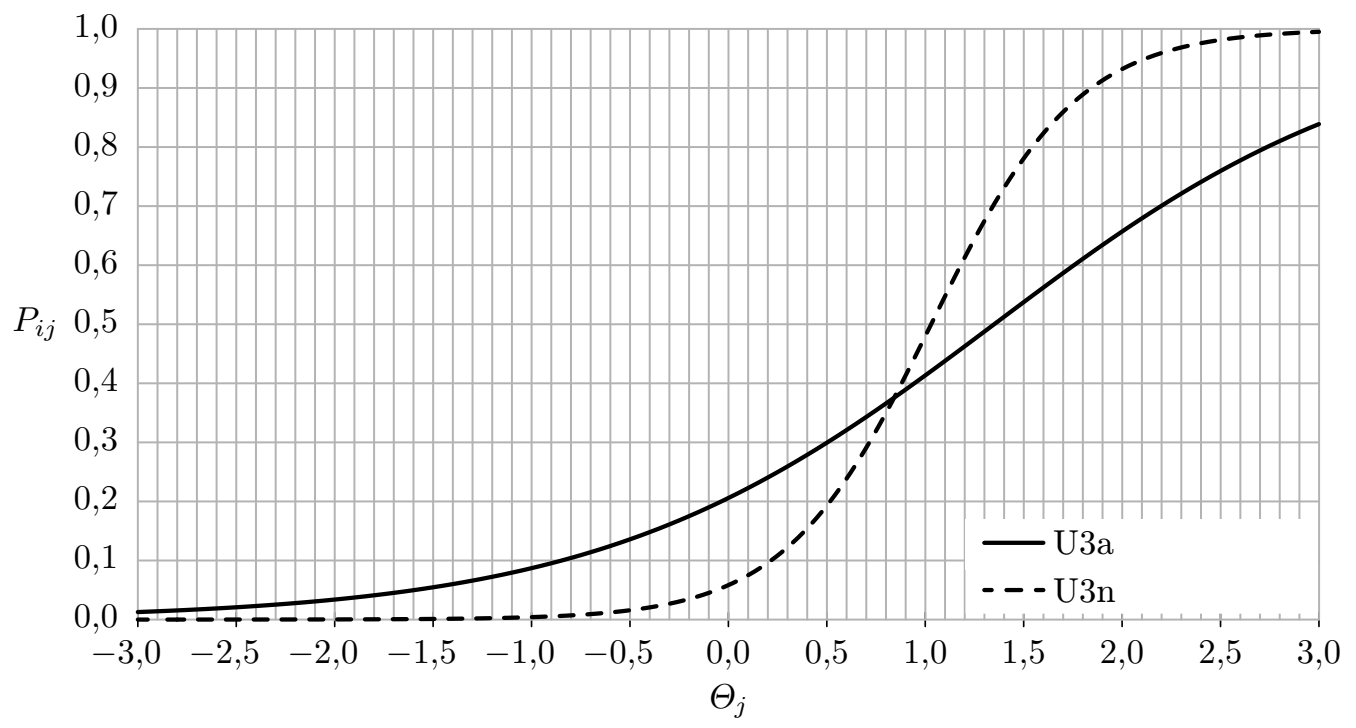

Obr. 8: IRT grafy pro obě varianty Úlohy 3

Tab. 10: Rozložení bodového zisku v obou variantách Úlohy 3 (5. ročník)

\begin{tabular}{lcccccccc}
\hline varianta & roč. & $N$ & 0 (nic) & 0 & 1 & 2 & 3 & úspěšnost \\
\hline atraktivní & 5 & 70 & $14 \%$ & $\mathbf{2 0} \%$ & $\mathbf{4 1} \%$ & $9 \%$ & $16 \%$ & $24 \%$ \\
\hline neutrální & 5 & 74 & $20 \%$ & $\mathbf{4 1} \%$ & $\mathbf{2 3} \%$ & $4 \%$ & $12 \%$ & $16 \%$ \\
\hline
\end{tabular}

*Tučně jsou vyznačeny rozdíly 10 p. b. a více.

\footnotetext{
${ }^{18}$ Tzv. signálem můžeme označit část zadání slovní úlohy, která vyvolává představu určité početní operace. Je-li tato operace v protikladu k operaci, kterou je třeba pro řešení úlohy použít, označujeme takový výraz antisignál. V naší literatuře jsou úlohy s touto charakteristikou popisovány jako úlohy s antisignálem nebo proti toku času (např. Hejný, 2014; Vondrová et al., 2019), v zahraniční literatuře jako inconsistent languge problems (např. Lewis \& Mayer, 1987).
} 
Tab. 11 ukazuje rozdíly ve frekvenci třech možných odpovědí (stihne, nestihne, nastejno), ty jsou překvapivě nezanedbatelné. Dva nejčastější chybné argumenty žáků vycházely z přesvědčení, že záleží pouze na rychlosti (otec/cyklista jel rychleji, proto Robina/traktor dohnal), nebo naopak pouze na čase výjezdu (otec/cyklista nemohl Robina/traktor dohnat, protože vyjel na cestu později). Na řešení Lukáše (obr. 9) je vidět další z frekventovaných jevů - operace s čísly v různých jednotkách, v tomto případě odčítání dráhy od rychlosti.

Tab. 11: Frekvence odpovědí v obou variantách Úlohy 3 (5. ročník)

\begin{tabular}{lcccc}
\hline varianta & celkem odpovědí & stihne & nestihne & nastejno \\
\hline atraktivní & 55 & $60 \%$ & $33 \%$ & $7 \%$ \\
\hline neutrální & 55 & $35 \%$ & $45 \%$ & $20 \%$ \\
\hline
\end{tabular}

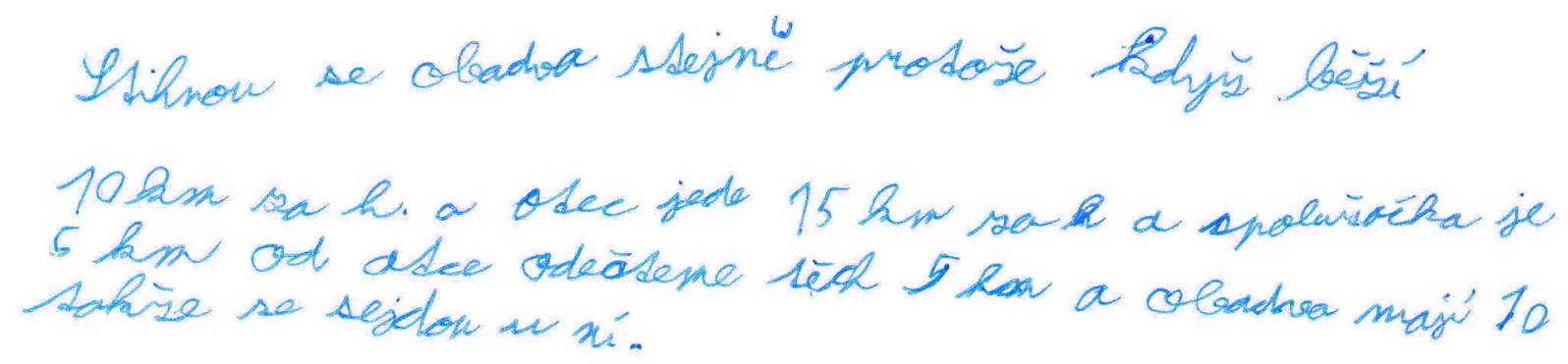

Obr. 9: Řešení Lukáše (varianta U3a) ${ }^{19}$

Opět jsme texty obou variant podrobili dodatečné analýze a s oporou o frekvenci nalezených chyb v žákovských řešeních hledali odlišnosti, které by vysvětlily rozdíl v úspěšnosti. Ve variantě s neutrálním kontextem je jednoznačněji vyjádřeno, odkud, kam a kudy traktor a cyklista jedou (po silnici z Adamova do Beranova), v opačné variantě to není vyjádřeno tak explicitně. Kromě délky textu (úspěšnější varianta U3a je delší, má 67 slov, varianta U3n má 53 slov), resp. přítomnosti nadbytečných informací jsme nenašli žádný další rozdíl ve vrstvě objektů, jejich vztahů ani v matematickém modelu. Když se podíváme na nadbytečná slova $\mathrm{v}$ textu atraktivní varianty, je zjevné, že jsou to právě ta slova, která tvoří příběhovou situační vrstvu úlohy:

Atraktivní varianta (U3a): Ve dvě hodiny př̀̌el Robin Prehal ze školy, položil na stůt ačal prchat. Prchal rychlostí 10 kilometrů $v$ hodině. $O$ čtvrt hodiny později si oznáment́ prečetl jeho otec, zrudl, nasedl na tř́kolku a začal syna stíhat rychlosti 15 kilometrů $v$ hodině. Stihne se Robin schovat u Zatloukalové, která bydli 5 kilometrů od Prchalových, dřive, než ho dožene otec? Svou odpověd' zdi̊vodni.

Při hodnocení řešení atraktivní varianty jsme si všimli také větší interakce žáků s kontextem úlohy. Do svých odpovědí volili expresivní nebo hovorové výrazy („zdrhne“, „tatkka“, „stihne to jen taktak“ apod.), zvažovali hypotetické scénáře („kdyby si to táta přečetl o půl hodiny později, tak by to stihl“) a kreslili ilustrační obrázky zachycující emoce. Nabízí se tedy jedno z možných vysvětlení pro tu téměř dvojnásobně vyšší frekvenci odpovědi „ano, stihne“ (tab. 11) ve variantě s Robinem - žáci Robinovi častěji přáli, aby se schovat stihl, a tak řešení svému přání podřizovali. Pro potvrzení této souvislosti by však bylo zapotřebí provést další rozhovory s žáky.

Z důvodu nízkého počtu žáků vyslovujeme celkové závěry s opatrností: naše předpoklady se potvrdily, byt rozdíly nebyly statisticky významné. Zjevné však je, že varianta s atraktivním kontextem probudila větší úsilí u žáků s nižší a střední latentní schopností.

\section{Diskuse}

Cúlem naší studie bylo zjistit, zda kontext, jakožto nematematická složka slovní úlohy, ovlivňuje úspěšnost žáků při jejím řešení a jejich ochotu úlohu vůbec řešit. Výzkumy zabývající se kontextem slovních úloh soustředily pozornost na různé jeho aspekty, zjištovaly např. efekt personalizace, familiárnosti, reálnosti, stylizovali úlohy do dívčí vs. chlapecké, dětské vs. „dospělácké“ podoby atd. Naše studie nabídla jinou

\footnotetext{
${ }^{19}$ Doslovný přepis textu: Stihnou se obadva stejně protože když běží $10 \mathrm{~km}$ za h a otec $15 \mathrm{~km}$ za h a spolužačka je $5 \mathrm{~km}$ od otce odečteme těch $5 \mathrm{~km}$ a obadva mají 10 takže se sejdou u ní.
} 
perspektivu - aspekt atraktivity. Vycházíme z předpokladu, že zvýšením atraktivity kontextu lze dosáhnout většího zájmu o slovní úlohu ze strany žáků a skrze něj pak také vyšší úspěšnosti. Vymezili jsme pojem atraktivní slovní úloha a vytvořili dvojice úloh se stejnou matematickou strukturou, z nichž jedna má kontext neutrální, druhá atraktivní.

Výsledky Úlohy 1 (Lichožrouti) a Úlohy 3 (Robin Prchal) potvrdily náš základní předpoklad, byt jen ve věcné rovině (rozdíly nebyly statisticky významné). Varianta Úlohy $1 \mathrm{~s}$ atraktivním kontextem měla vyšší procento úspěšných řešitelů, přitom stejně dobrou diskriminační schopnost jako odpovídající varianta s neutrálním kontextem. Ani analýza chyb neodhalila žádné nezamýšlené rozdíly mezi oběma variantami, tedy mírně vyšší úspěšnost lze přičist kontextu. V Úloze 3 se ukázalo, že atraktivní kontext může výrazně zvýšit úspěšnost žáků s nižší a střední latentní schopností. Přestože celkový rozdíl kvưli odlišné diskriminaci variant a obecně nízkému počtu správných řešení není statisticky významný, lze dovodit, že i v tomto př́padě vyšší úspěšnost zapř́ččinil kontext.

Úloha 2 ukázala opačnou tendenci. Varianta s kontextem, který jsme považovali za atraktivní, byla pro žáky obtížnější než varianta s kontextem neutrálním, přičemž rozdíl v úspěšnosti byl statisticky významný. Analýza chyb potvrdila, že žáci řešící atraktivní variantu častěji sahali k povrchovým strategiím a v jejich postupech znatelně narostla frekvence chyb. Dodatečná analýza této úlohy nás upozornila na dvě důležité věci. Jednak na to, že se změnou kontextu může přijít celá řada drobných nezamýšlených změn v dalších parametrech úlohy, které mohou v součinnosti znesnadnit žákům vytvořit si správnou představu o úloze (situační model). K druhému poznání jsme dospěli při snaze porovnat naše výsledky se závěry jiných výzkumů - určité aspekty kontextu lze nahližet z různých perspektiv, stejné aspekty lze označovat různými výrazy.

Jako první se nabízí srovnání s výzkumem Wiest(ové) (1998), nebot ta se zabývala efektem př́ibuzných fantasy kontextů. Připodobněním naší studie se sci-fi kontextem bychom mohli nabýt dojmu, že naše výsledky jsou v rozporu, nebot její výzkum ukázal, že úlohy s fantasy kontextem měly stejnou nebo vyšší úspěšnost v porovnání s kontexty neutrálními. Když se ale na náš atraktivní sci-fi kontext podíváme jako na kontext nefamiliární, tedy takový, se kterým děti nemají zkušenosti, naše výsledky budou naopak v souladu se čtyřmi výzkumy zaměřenými na familiárnost kontextu, které popisuje Hembree ve své metaanalýze (1992). Stejně tak bychom mohli jeden z našich kontextů označit za dívčí (oslavy jako doména žen, dívčí postavy) a druhý chlapecký (válečná tematika) a porovnávat výsledky se Zohar(ovou) a Gershikov(ovou) (2008). Naše zjištění by byla v těsném souladu - ve sci-fi chlapeckém kontextu byli úspěšnější chlapci, v dívčím kontextu byli také úspěšnější chlapci, i když s menším náskokem. Celá problematika tak dostává jinou podobu. Na nekonzistenci výzkumů v př́stupech $\mathrm{k}$ problematice kontextů upozornil již dřive např. Palm (2008) a Ulovec (2018), kteří se zabývají zejména aspektem reality ve slovních úlohách. Sám Palm přitom ve svém výzkumu (2008) varioval aspekt autenticity kontextu (less authentic vs. more authentic problems), ale spolu s ním změnil úlohu ve třech dalších parametrech (personalizace, jazyková explicitnost a délka textu). ${ }^{20}$ To nás přivádí $\mathrm{k}$ obecné problematice parametrizace a klasifikace kontextů slovních úloh a nutnosti posuzovat je z různých perspektiv. Domníváme se také, že je to současně př́činou nejasného trendu a rozcházejících se výsledků dosavadních výzkumů v této oblasti.

Otázka typologie a pojmenování kontextů začne být důležitá zejména v okamžiku, kdy uvažujeme o přesahu těchto výzkumů do praxe. Jaké závěry si mají z našich studií odnést učitelé, tvưrci učebnic nebo diagnostických testů? Doporučíme jim, aby používali fantasy kontexty? Nebo aby se vyhnuli kontextům nefamiliárním a drželi se reality? Vpustíme-li do úvah ještě individualitu každého žáka, je možné vůbec vyslovit nějaká obecně platná doporučení? Kritérium atraktivity je do značné míry subjektivní. Potvrdily to např́́klad i rozhovory se žáky (Wiest, 1998). Zatímco někteří uváděli, že na kontextu úlohy nezáleží, jiní poukazovali dokonce na jeho negativní efekt - atraktivní kontext odvedl jejich pozornost od řešení. Někteř́ žáci naopak mluvili o nudě, kterou v nich určité kontexty vyvolávají či o nepřiměřenosti úlohy vzhledem $\mathrm{k}$ jejich věku. Žák 6 . ročníku např́klad v rozhovoru popsal, že jinak přistupuje k úlohám, jehož kontext ho nezaujal (text úlohy nečte celý, ale pouze vybere nezbytné údaje), a jinak k úlohám se zajímavým kontextem. Např. explicitně zmínil, že úlohu inspirovanou sci-fi si s chutí přečte celou. Také v naší pilotní studii se objevovaly argumenty ve prospěch obou variant kontextů (Havličková, 2020).

I přes výše řečené se domníváme, že zabývat se různými aspekty kontextu slovní úlohy a pátrat po kontextech pro žáky atraktivních, at již svou humorností, reálností nebo fantazijností, má smysl. Náš výzkum ukázal, že tyto kontexty mohou přinést určité zvýšení úspěšnosti, jsou-li vhodně zvoleny a bez příměsi dalších parametrů, které komplikují žákovské porozumění. Kontext slovní úlohy je jedním z parametrů, skrze které lze nastavit obtížnost slovní úlohy, a přizpůsobit ji tak individuálním potřebám žáka.

\footnotetext{
${ }^{20}$ Př́́kladem je dvojice úloh: „360 students shall go by bus on a school trip. Each bus can hold 48 students. How many buses are required?" vs. "All students in the school will go on a school trip together on the 15th of May. You and the otherorganizing students have decided that everyone will go by bus, and that you will order the buses. You have seen in the student rosters that there are 360 students in the school. Your teacher said that you can order the buses from Swebus, and that each bus can hold 48 students."
} 
V další fázi výzkumu bychom se chtěli zaměřit na negativní efekt atraktivity kontextu, kterého jsme byli svědkem při pilotních rozhovorech s žáky (atraktivita odvádí pozornost a zhoršuje tak jejich výkon), a dále na oveření vlivu zaujetí úkolem (Kmínková \& Pavelková, 2011) na tendenci řešit slovní úlohu povrchovými strategiemi. $\mathrm{K}$ tomuto účelu nebylo možné tři úlohy $\mathrm{z}$ předložené studie použít. Úloha 1 nevedla k povrchové strategii ani v jedné $\mathrm{z}$ variant, v Úloze 2 nelze rozdíly připisovat atraktivitě kontextu, nebot se varianty úlohy lišily ve více parametrech, a Úloha 3 byla pro žáky v obou variantách př́liš obtížná. Pozornost by si zasloužilo rovněž prozkoumání různých věkových, genderových, socioekonomických, regionálních a jiných skupin žáků z hlediska jejich preferencí určitých kontextů.

\section{Závěr a omezení výzkumu}

Naše studie nabídla novou perspektivu nahližžení na kontext slovní úlohy. Přestože se může zdát, že výsledky zařadily naši studii mezi výzkumy, jejichž závěry jsou vnitřně rozporné a vyvolávají více otázek, než přináší odpovědí, domníváme se, že vynesly na světlo tři důležité věci. První je skutečnost, že některé kontexty opravdu mohou zvýšit zájem žáků o jejich řešení. Otázkou zůstává, jak takové kontexty hledat. Druhá spočívá v uvědomění, že některé aspekty kontextu lze nahlížet z různých perspektiv, a proto je v podobných výzkumech zapotřebí pečlivěji zvažovat zkoumané varianty úloh. Jako velmi žádoucí se proto jeví revize dosavadních výzkumů zabývajících se vlivem kontextu slovní úlohy na úspěšnost žáka, která by mohla najít určitou skrytou konzistenci. Třetí je potvrzení zřejmého faktu, že atraktivita úlohy je parametr do značné míry subjektivní, z čehož plynou další již méně zřejmé důsledky pro učitele či tvưrce učebnic. Např. že obsahy učebnic mohou rychle stárnout a skrze nabízené neaktualizované kontexty vyvolávat negativní motivační efekt (způsobovat nezájem žáků o slovní úlohu nebo dokonce odpor). Je proto třeba vnímat učebnice jako živý materiál, který lze upravovat a přizpůsobovat potřebám žáků.

Jednou z předností a zároveň jedním z limitů naší studie je intenzivní a velkoplošné testování, v rámci něhož vznikala (Vondrová et al., 2019). Potřeba získat dostatečné množství dat pro kvantitativní šetření znamenala vzdát se možnosti individuálního pozorování testovaných žáků při řešení. Rozhovory se žáky by poskytly přiléhavější představu o řešitelském procesu a původu chyb.

Za silnou stránku našeho výzkumu považujeme využití Item Response Theory, která na rozdíl od obvykle použivané klasické teorie testů v podobných výzkumech umožňuje propojit obtížnost a diskriminaci testované úlohy s latentní schopností každého žáka a rozdělit testované žáky do výkonově srovnatelných skupin (nejen podle známek na vysvědčení či výsledku jednorázového testu). Kromě větší reliability výsledků nám tato teorie umožnila sledovat, jak na různé druhy kontextů reagují žáci s různými schopnostmi $\mathrm{v}$ matematice a v českém jazyce.

Výsledky našeho výzkumu a jejich diskuse mohou přispět odborné veřejnosti při zkoumání parametrů slovních úloh. Na př́íladu Úlohy 2 a rešerši př́slušných výzkumů se ukázalo, že se změnou jednoho parametru úlohy může snadno a nepozorovaně dojít ke změně dalších, které znečitelní efekt sledovaného parametru. Toto upozornění může být důležité také pro tvůrce diagnostických a srovnávacích testů, kteří mohou uvědoměleji zacházet s parametry úloh.

\section{Poděkování}

Tento článek vznikl za podpory Grantové agentury České republiky v rámci grantového projektu Slovní úlohy jako klíč k aplikaci a porozuměni matematickým pojmům (GA16-06134S).

\section{Literatura}

Beswick, K. (2011). Putting context in context: An examination of the evidence for the benefits of 'contextualised' tasks. International Journal of Science and Mathematics Education, 9(2), 367-390. https://doi.org/10.1007/s10763-010-9270-z

Boaler, J. (1993). The role of contexts in the mathematics classroom: Do they make mathematics more "real"? For the Learning of Mathematics, 13(2), 12-17. https://www.jstor.com/stable/40248079

Borasi, R. (1986). On the nature of problems. Educational Studies in Mathematics, 17(2), 125-141. https://doi.org/10.1007/BF00311517

Bottge, B. A. (1999). Effects of contextualized math instruction on problem solving of average and below-average achieving students. The Journal of Special Education, 33(2), 81-92. https://doi.org/10.1177/002246699903300202

Cooper, B., \& Harries, T. (2002). Children's responses to contrasting 'realistic' mathematics problems: Just how realistic are children ready to be? Educational Studies in Mathematics, 49(1), 1-23.

https://doi.org/10.1023/A:1016013332659 
Daroczy, G., Wolska, M., Meurers, W.D., \& Nuerk, H. C. (2015). Word problems: a review of linguistic and numerical factors contributing to their difficulty. Frontiers in Psychology, 6(348), 22-34. https://doi.org/10.3389/fpsyg.2015.00348

De Bock, D., Verschaffel, L., Janssens, D., Van Dooren, W., \& Claes, K. (2003). Do realistic contexts and graphic representations always have a beneficial impact on students' performance? Negative evidence from a study on modelling non-linear geometry problems. Learning and Instruction, 13(4), 441-463. https://doi.org/10.1016/S0959-4752(02)00040-3

Gersten, R., Chard, D. J., Jayanthi, M., Baker, S. K., Morphy, P., \& Flojo, J. (2008). Mathematics instruction for students with learning disabilities or difficulty learning mathematics: A synthesis of the intervention research. Center on Instruction. https://files.eric.ed.gov/fulltext/ED521890.pdf

Havlíčková, R. (2020). Vliv atraktivity kontextu slovní úlohy na úspěšnost a motivaci žáků. [Disertační práce, Pedagogická fakulta Univerzity Karlovy]. (v prř́pravě)

Hejný, M. (2003). Anatómia slovnej úlohy o veku. Disputationes scientificae Universitatis Catholicae in Ružomberok, 3(3), 21-32. http://math.ku.sk/data/konferenciasub/pdf2003/Hejny.pdf

Hejný, M. (2014). Vyučování matematice orientované na budování schémat: aritmetika 1. stupně. Univerzita Karlova v Praze, Pedagogická fakulta.

Hembree, R. (1992). Experiments and relational studies in problem solving: A meta-analysis. Journal for Research in Mathematics Education, 23(3), 242-273. https://doi.org/10.2307/749120

Kmínková, E., \& Pavelková, I. (2011). Obtížnost a zaujetí úkolem v matematice. In T. Janík, P. Knecht, \& S. Šebestová (Eds.), Smišený design v pedagogickém výzkumu: Sborník př́ispěvků z 19. výročni konference Ceské asociace pedagogického výzkumu (s. 434-438). Masarykova univerzita.

http://www.ped.muni.cz/capv2011/sbornikprispevku/kminkovapavelkova.pdf

Lewis, A. B., \& Mayer, R. E. (1987). Students' miscomprehension of relational statements in arithmetic word problems. Journal of Educational Psychology, 79(4), 363-371. https://doi.org/10.1037/0022-0663.79.4.363

López, C. L., \& Sullivan, H. J. (1992). Effect of personalization of instructional context on the achievement and attitudes of hispanic students. Educational Technology Research and Development, 40(4), 5-14. https://doi.org/10.1007/BF02296895

Lord, F. M. (1980). Applications of item response theory to practical testing problems. Lawrence Erlbaum Associates.

Man, F., \& Mareš, J. (2005). Výkonová motivace a prožitek typu flow. Pedagogika, 55(2), 151-171. https://pages.pedf.cuni.cz/pedagogika/?p=1668\&lang $=$ cs

Meyer, M.R., Dekker, T., \& Querelle, N. (2001). Context in mathematics curricula. Mathematics Teaching in the Middle School, 6(9), 522-527.

Murphy, L. O., \& Ross, S. M. (1990). Protagonist gender as a design variable in adapting mathematics story problems to learner interests. Educational Technology Research and Development, 38(3), 27-37. https://doi.org/10.1007/bf02298179

Nesher, P., Hershkovitz, S., \& Novotná, J. (2003). Situation model, text base and what else? Factors affecting problem solving. Educational Studies in Mathematics, 52(2), 151-176. https://doi.org/10.1023/A:1024028430965

Nesher, P., \& Teubal, E. (1975). Verbal cues as an interfering factor in verbal problem solving. Educational Studies in Mathematics, 6(1), 41-51. https://doi.org/10.1007/BF00590023

Novotná, J. (2000). Analýza řešení slovních úloh. Univerzita Karlova v Praze, Pedagogická fakulta.

Organisation for Economic Co-operation and Development. (2010). Learning mathematics for life: A perspective from PISA. OECD Publishing. https://doi.org/10.1787/9789264075009-en

Palm, T. (2008). Impact of authenticity on sense making in word problem solving. Educational Studies in Mathematics, 67(1), 37-58. https://doi.org/10.1007/s10649-007-9083-3

Rendl, M., Vondrová, N., Hř́ibková, L., Jirotková, D., Kloboučková, J., Kvasz, L., Páchová, A., Pavelková, I., Smetáčková, I., Tauchmanová, E., \& Žalská, J. (2013). Kritická mista matematiky na základní škole očima učiteli̊. Pedagogická fakulta, Univerzita Karlova.

Reusser, K. (1990). Understanding word arithmetic problems. Linguistic and situational factors [Paper presentation]. Annual Meeting of the American Educational Research Association, Boston, MA. https://eric.ed.gov/?id=ED326391

Rheinberg, F., Man, F., \& Mareš, J. (2001). Ovlivňování učební motivace. Pedagogika, 51(2), 155-184. https://pages.pedf.cuni.cz/pedagogika/?p=2165\&lang $=c s$ 
Sweller, J. (2010). Element interactivity and intrinsic, extraneous, and germane cognitive load. Educational Psychology Review, 22(2), 123-138. https://doi.org/10.1007/s10648-010-9128-5

Šrut, P., \& Miklínová, G. (2008). Lichožrouti. Paseka.

Tzohar-Rozen, M., \& Kramarski, B. (2014). Metacognition, motivation and emotions: Contribution of self-regulated learning to solving mathematical problems. Global Education Review, 1(4), 76-95.

https://files.eric.ed.gov/fulltext/EJ1055263.pdf

Verschaffel, L., \& De Corte, E. (1993). A decade of research on word problem solving in Leuven: Theoretical, methodological, and practical outcomes. Educational Psychology Review [online], 5(3), 239-256.

https://doi.org/10.1007/BF01323046

Verschaffel, L., De Corte, E., \& Pauwels, A. (1992). Solving compare problems: An eye movement test of Lewis and Mayer's consistency hypothesis. Journal of Educational Psychology, 84(1), 85-94.

https://doi.org/10.1037/0022-0663.84.1.85

Verschaffel, L., Greer, B., \& De Corte, E. (2000). Making sense of word problems. Swets \& Zeitlinger Publishers.

Ulovec, A. (2018). Reality? An analysis of text books' "real life" tasks. [Přednáška]. Didakticko-matematický seminář KMDM PedF UK.

Vondrová, N. (2020). Příčiny použivání povrchových strategií řešení slovních úloh a jak jim předcházet. Učitel matematiky, 28(2), 66-93.

Vondrová, N., Havlíčková, R., Hirschová, M., Chvál, M., Novotná, J., Páchová, A., Smetáčková, I., Šmejkalová, M., \& Tůmová, V. (2019). Matematická slovní úloha: mezi matematikou, jazykem a psychologií. Nakladatelství Karolinum.

Vondrová, N., \& Novotná, J. (2017). The influence of context and order of numerical data on the difficulty of word problems for grade 6 pupils. In J. Novotná, \& H. Moraová (Eds.), Proceedings of SEMT '17 (pp. 440-449). Charles University, Faculty of Education.

Wiest, L. R. (1998). The role of fantasy and real-world problem contexts in fourth-and sixth-grade students' mathematical problem solving. Paper presented at the Annual Meeting of the American Educational Research Association (San Diego, CA, April 13-17, 1998). https://eric.ed.gov/?id=ED425910

Zohar, A., \& Gershikov, A. (2008). Gender and performance in mathematical tasks: Does the context make a difference? International Journal of Science and Mathematics Education, 6(4), 677-693.

https://doi.org/10.1007/s10763-007-9086-7

\section{Př́loha 1}

\section{Obecné jevy sledované u všech úloh}

\begin{tabular}{|c|c|c|}
\hline označení & popis & kód \\
\hline $\mathrm{XXo0}$ & v řešení není nic napsáno & $0-1$ \\
\hline XXo01 & v řešení je jen správný výsledek bez náznaku řešení & $0-1$ \\
\hline XXo11 & přítomnost slovní legendy & $0-1$ \\
\hline XXo12 & přítomnost tabulkové legendy & $0-1$ \\
\hline XXo13 & přítomnost obrázkové legendy & $0-1$ \\
\hline XXo14 & přítomnost algebraické legendy & $\overline{0-1}$ \\
\hline XXo2 & přítomnost zápisu postupu řešení & $0-1$ \\
\hline$\overline{\mathrm{XXo31}}$ & př́itomnost správné slovní odpovědi & $0-1$ \\
\hline XXo32 & $\begin{array}{l}\text { přítomnost nesprávné slovní odpovědi (gramatické chyby nebereme v úvahu; } \\
\text { nesprávnost z hlediska slovní úlohy - např. odpovídá na jinou otázku) }\end{array}$ & $0-1$ \\
\hline XXo33 & chybí odpověd', ale v řešení je jiné označení výsledku jednoznačným způsobem & $0-1$ \\
\hline XXo41 & ukončení výpočtu dílčím výsledkem, který řešitel považuje za konečný & $0-1$ \\
\hline XXo42 & $\begin{array}{l}\text { ukončení výpočtu dílčím výsledkem, který řešitel nepovažuje za konečný (z nějakého } \\
\text { důvodu, který nemůžeme znát, už dál nepokračoval) }\end{array}$ & $\overline{0-1}$ \\
\hline XXo5 & využití všech relevantních údajů ze zadání & $0-1$ \\
\hline
\end{tabular}

*kód 0: jev není př́ítomen; kód 1: jev je přítomen 
Specifické jevy sledované u Úlohy 2 - Hvězdné impérium: řešitelské postupy

\begin{tabular}{clr}
\hline označení & popis & kód \\
\hline p1 & zjištění počtu zasažených faunů fregatou/kamarádek Bely $(9+4)$ & $0-1-2-3$ \\
\hline p2 & zjištění počtu zasažených faunů bitevním křižníkem/kamarádek Lei $(9+9+4)$ & $0-1-2-3$ \\
\hline p3 & $\begin{array}{l}\text { zjištění počtu všech zasažených faunů/všech pozvaných kamarádek } \\
(9+9+4+9+9+4)\end{array}$ & $0-1-2-3$ \\
\hline p4 & zjištění počtu všech faunů vyslaných do bitvy/přičtení rodiny $(x+11)$ & $0-1-2-3$ \\
\hline p5 & jiný postup (v poznámce stručně popsat jaký) & $0-1-2-3$ \\
\hline
\end{tabular}

*kód 0: postupový krok (dále PK) není přítomen; kód 1: PK je př́tomen a zcela správně; kód 2: PK je př́tomen pouze s numerickou chybou; kód 3: PK je př́tomen s logickou chybou (nesprávnost nelze přisoudit numerické chybě)

\section{Specifické jevy sledované u Úlohy 2 - Hvězdné impérium: chyby}

\begin{tabular}{clr}
\hline označení & popis & kód \\
\hline ch1 & $\begin{array}{l}\text { vynechání jedné nebo více součástí výpočtu: } 9,(9+4),(9+9+4), 11 \text { (v poznámce } \\
\text { specifikovat které) }\end{array}$ & $0-1$ \\
\hline ch2 & povrchová strategie (prostý součet všech čísel v zadání) & $0-1$ \\
\hline ch3 & záměna „o 4 více“ za ,4× více“ & $0-1$ \\
\hline ch4 & odečtení 11 & $0-1$ \\
\hline ch5 & připočítání trojčat & $0-1$ \\
\hline ch6 & numerická chyba nebo chyba v algoritmu (v poznámce specifikovat jaká) & $0-1$ \\
\hline ch7 & jiná chyba (v poznámce stručně popsat jaká) & $0-1$ \\
\hline
\end{tabular}

*kód 0: jev není př́tomen; kód 1: jev je př́itomen 